\title{
Large Investors, Price Manipulation, and Limits to Arbitrage: An Anatomy of Market Corners
}

\author{
Franklin Allen ${ }^{*}$, Lubomir Litov ${ }^{* *}$, and JianPing Mei ${ }^{* * *}$
}

Draft of $12 / 30 / 2004$

\begin{abstract}
Using a novel hand-collected data set we investigate price and trading behavior around several well-known stock market and commodity corners which occurred between 1863 and 1980. We find strong evidence that large investors and corporate insiders possess market power that allowed them to manipulate prices. Manipulation leading to a market corner tends to increase market volatility and has an adverse price impact on other assets. We also find that the presence of large investors makes it extremely risky for would-be short sellers to trade against the mispricing. Therefore, regulators and exchanges need to be concerned about ensuring that corners do not take place since they are accompanied by severe price distortions.
\end{abstract}

JEL Classification: G14, G18, K22.

Keywords: Manipulation; Market Corner; Limits to Arbitrage.

\footnotetext{
* Nippon Life Professor of Finance and Professor of Economics, Department of Finance, The Wharton School of the University of Pennsylvania, Philadelphia, PA 19104-6367, phone 215-898-3629, fax: 215-5732207, email: allenf@wharton.upenn.edu.

** Doctoral student, Leonard Stern School of Business, New York University, New York 10012, phone: 212998-0883, fax: 212-995-4218, email: $\underline{\text { litov@stern.nyu.edu. }}$

${ }^{* * *}$ Associate Professor of Finance, Leonard Stern School of Business, New York University, New York NY 10012 and CCFR, phone: 212-998-0354, email: jmei@stern.nyu.edu.

We are grateful to Niall Ferguson, William Goetzmann, Richard Sylla, Jeffrey Wurgler, and conference participants at the CEPR Conference on Early Securities Markets at the Humboldt University on October 1516, 2004 for valuable discussions and comments.
} 


\title{
Large Investors, Price Manipulation, and Limits to Arbitrage: An Anatomy of Market Corners
}

\begin{abstract}
Using a novel hand-collected data set we investigate price and trading behavior around several well-known stock market and commodity corners which occurred between 1863 and 1980. We find strong evidence that large investors and corporate insiders possess market power that allowed them to manipulate prices. Manipulation leading to a market corner tends to increase market volatility and has an adverse price impact on other assets. We also find that the presence of large investors makes it extremely risky for would-be short sellers to trade against the mispricing. Therefore, regulators and exchanges need to be concerned about ensuring that corners do not take place since they are accompanied by severe price distortions.
\end{abstract}




\section{Introduction}

Although stock markets are far better regulated today than in the nineteenth century, market manipulations by large investors and insiders still occur around the world. Most recently, in August 2004, Citigroup sold more than 200 different Eurozone bonds in the space of 2 minutes. After the price fell they bought some back again at lower prices. They are thought to have netted $€ 15$ million. ${ }^{1}$ This action reduced the subsequent liquidity of the market significantly. In May 1991, a bond trader at Salomon Brothers was discovered attempting to corner the market in two-year U.S. Treasury notes. ${ }^{2}$ During the 1990s bull market, numerous price manipulation schemes for penny stocks were discovered by the SEC. ${ }^{3}$ Manipulation knows no international borders. In 2002, China's worst stock-market crime was a scheme to manipulate the share price of a firm called China Venture Capital. Seven people, including two of the firm's former executives, were accused of using $\$ 700$ million and 1,500 brokerage accounts nationwide to manipulate the company share price. Krugman (1996) also reported a price manipulation in the copper market by a rogue trader at the Japanese trading firm Sumitomo.

There is a small but growing theoretical literature on market manipulation. Hart (1977), Hart and Kreps (1986), Vila (1987, 1989), Allen and Gale (1992), Allen and Gorton (1992), Benabou and Laroque (1992), and Jarrow (1992, 1994) were among the first to study market manipulation. Cherian and Jarrow (1995) survey this early literature. Subsequent contributions include Bagnoli and Lipman (1996), Chakraborty and Yilmaz (2003, 2004), and Goldstein and Guembel (2003). Kumar and Seppi (1992) discuss the possibility of futures manipulation with cash settlement. Pirrong (1993) shows how squeezes hinder price discovery and create deadweight losses. Vitale (2000) considers manipulation in foreign exchange markets. Van Bommel (2003) shows the role of rumors in facilitating price manipulation.

In contrast, the empirical literature is quite limited. Although the wide-spread manipulation through stock pools before the Crash of 1929 is vividly documented in Galbraith (1972), Mahoney (1999) and Jiang, Mahoney, and Mei (2004) find little

\footnotetext{
${ }^{1}$ See the Financial Times, September 10, 2004, p. 11.

2 See Jegadeesh (1993) and Jordan and Jordan (1996) for detailed studies on the Treasury auction bids and the Salomon price squeeze.

${ }^{3}$ For example, the SEC intervened in 1996 when the share price of Comparator Systems Corporation (a finger print identification company with net assets of less than $\$ 2$ million) soared from 3 cents to $\$ 1.03$, valuing the company at a market capitalization of over a billion dollars. An astonishing 180 million Comparator shares were traded on the Nasdaq Exchange on May 6, 1996. See also Aggarwal and Wu (2003).
} 
evidence of price manipulation for the stock pools. However, there are a few recent studies that have found evidence of market manipulation. Aggarwal and Wu (2003) present a theory and some empirical evidence on stock price manipulation in the United States. Extending the framework of Allen and Gale (1992), they show that more information seekers imply greater competition for shares in a market with manipulators, making it easier for a manipulator to enter the market and potentially worsen market efficiency. Using a unique dataset from SEC actions in cases of stock manipulation, they find that more illiquid stocks are more likely to be manipulated and manipulation increases stock volatility. Khwaja and Mian (2004) discover evidence of broker price manipulation by using a unique daily trade level data set from the main stock market in Pakistan. They find that brokers earn at least $8 \%$ higher returns on their own trades. While neither market timing nor liquidity provision offer sufficient explanations for this result, they find compelling evidence for a specific trade-based “pump-and-dump” price manipulation scheme. Merrick, Nain and Yadav (2004) provide empirical evidence on learning in the market place and on the strategic behavior of market participants by studying an attempted delivery squeeze in the March 1998 long-term UK government bond futures contract traded on the London International Financial Futures and Options Exchange (LIFFE). Felixon and Pelli (1999) test for closing price manipulation in the Finnish stock market and find evidence of it. They find that block trades and spread trades explained a part, but not all of the observed manipulation. Mei, Wu and Zhou (2004) construct a theoretical example in which smart money strategically takes advantage of investors' behavioral biases and manipulates the price process to make profit. As an empirical test, the paper presents some empirical evidence from the U.S. SEC prosecution of "pump-and-dump" manipulation cases. The findings from these cases are consistent with their model.

This paper fills a gap in the manipulation literature by providing a clinical study on a particular form of manipulation - market corners from the robber-baron era to the Great Depression of 1929 to the 1980s. ${ }^{4}$ We make several contributions to the literature on market manipulation: first, we have put together by hand a novel data set of price and trading volume based on historical newspapers from the New York Times and the Wall Street Journal from 1863-1980. This allows us to provide the first systematic account of some well-known market corners in US financial history. Second, we present some unique

\footnotetext{
${ }^{4}$ Jarrow (1992) provides a collection of early references on attempted corners in individual common stocks.
} 
evidence on the price and volume patterns of successful corners. We show that market corners tend to increase market volatility and have an adverse price impact on other assets. Third, we demonstrate that the presence of large investors makes it extremely risky for short sellers to trade against mispricing in the stock market. This creates severe limits to arbitrage in the stock market that impede market efficiency. Therefore, regulators and exchanges need to ensure that corners do not take place since they are accompanied by severe price distortions.

The structure of the paper is as follows. Section II considers the data and institutional background. The empirical results are presented in Section III. Section IV contains concluding remarks.

\section{Historical Data and Institutional Background}

One of the main hurdles in studying market manipulation is that the data are hard to obtain since the activity is often illegal and thus the participants do their best to hide it. Aggarwal and Wu (2003) and Mei, Wu and Zhou (2004) get around this problem by using prosecution cases filed by the SEC. This paper overcomes the hurdle by looking at a special form of manipulation - market corners. We identify market corners by going through the stock market chronology compiled by Wyckoff (1972). He defines a corner as “a market condition brought about intentionally - though sometimes accidentally - when virtually all of the purchasable, or floating, supply of a company's stock is held by an individual, or group, who are thus able to dictate the price when settlement is called." Thus, a corner is an extreme form of short squeeze, when the buy side has almost complete control of all floating shares.

We check all the corners reported by Wyckoff (1972) using reports by Brooks (1969), Clews (1888), Sobel (1865), Stedman (1905), and Thomas (1989). We eliminate those that cannot be verified independently and we restrict our cases to those that happened between 1863 and 1928, because trading data were not available before 1863 . The New York Stock Exchange passed rules to discourage market corners in 1920, after which only one corner was reported (Piggly-Wiggly) while the RCA corner in 1928 was unplanned. ${ }^{5}$ This gives a total of thirteen reported cases of stock corners. In addition, we also include

\footnotetext{
${ }^{5}$ Strictly speaking, the RCA corner is more like a short squeeze because no settlement was called. The reason we included it is because the manipulator Durant was reported to have controlled the whole float.
} 
the case of the failed silver corner of the Hunt brothers in 1980. The corners considered are shown in Table 1.

We hand-collected the data set of price and trading volume from the New York Times and we use the Wall Street Journal to search for information that is missing due to the poor publication quality of historical newspapers. This is a laborious process since we also need to aggregate trade-by-trade information in order to get daily price and trading volume. ${ }^{6}$ Based on Wyckoff's definition, we break corners into two categories: successful and failed corners. Successful corners are those where the manipulator controlled almost all of the floating shares during the short squeeze and was able to dictate prices. Failed corners are those where the manipulators attempted but failed to control the large amount of floating shares either because of large amounts of new shares that were brought to the market on the settlement date or because of government action. The corner dates are determined based on either the settlement call made by the manipulators or government action dates. Appendix A provides a brief account of most of the corners while Appendix B provides a graphical depiction of trading activity around the corner dates.

There are several common features of these corners. First of all, most corners involved the robber-barons of the time, namely, Jay Gould, Daniel Drew, Jim Fisk, Cornelius Vanderbilt, and J. P. Morgan. Many of them were in a special position to exploit unwary investors - in many cases they were corporate officers/insiders as well as large stockholders. ${ }^{7}$ Second, manipulators often controlled a huge amount of the common shares, often exceeding the whole float at the time of settlement, which put them in a position to dictate the settlement price to the short sellers. Third, stock prices tend to be discontinuous for cornered stocks, often with large price jumps around the corner date, suggesting major disruptions to an orderly market. Fourth, the amount of wealth controlled by the manipulators was large compared to the market cap of the stock. ${ }^{8}$

\footnotetext{
${ }^{6}$ Unfortunately, while the New York Times reports every trade for each stock before 1900, the trades were not time-stamped so that we cannot perform microstructure studies.

${ }^{7}$ For example, as director of Erie, Drew had used his position to issue new shares to cover his short position. He also had hidden convertible bonds that were unknown to the market but were convertible to common when he was cornered.

${ }^{8}$ According to Gordon (1999), Vanderbilt put together a stock pool of $\$ 5$ million in cash to operate the second Harlem corner. At the time, he already owned a big chunk of Harlem stocks due to the first Harlem corner. On March 29, 1864, Harlem had a market capitalization of \$11.9million with 110,000 shares outstanding. By the end of April, Vanderbilt and his allies owned 137,000 shares, with the difference sold to them by the short sellers. At time of his death in 1877, Vanderbilt left an estate that was worth \$90 million.
} 
The presence of deep-pocketed manipulators makes short-selling an extremely hazardous venture for would-be arbitrageurs. The oldest and most sacred rule of Wall Street at the time was “He who sells what isn't his, Must buy it back or go to prison.” As pointed out by Jones and Lamont (2002), there are two main risks for short sellers: first, short sellers are required to post additional collateral if the price of the shorted stock rises. Second, stock loans can be called at the discretion of the lender, giving rise to recall risk.

Manipulation will exacerbate the above risks and add some new risks to the arbitrageurs. First of all, when manipulators are better informed about the supply of shares, the short sellers are more likely to close their position at a loss. The lender of the stock would demand the return of her shares at the worst possible time. The stock lender/ manipulator will call in her loan when the shares have risen in price and the short sellers are unable to find shares to borrow. Second, deep-pocketed manipulators will be able to drive stock prices to the point where short sellers would not be able to post additional collateral and thus have to close their position at a loss. Third, the price jumps during a market corner create a huge operational risk for brokers who arrange stock borrowing for short sellers. In the event of a market corner, large jumps in stock price could easily wipe out the collateral put up by short sellers and lead to severe financial losses for the broker in the event of short seller default. ${ }^{9}$ In this case, because of lack of liquidity in the market, it may be difficult for brokers to protect themselves by closing short-sellers’ position.

\section{Empirical Results}

The data for this study is collected from historical records of the New York Times and The Wall Street Journal (see Table 1 for the corresponding time periods). Nine of the documented corners took place in the second half of the nineteenth century and five took place throughout the twentieth century. A concise historical reference on each of these corners is presented in Appendix A. In the process of building the historical trading database we have aggregated intra-day transactions on a daily basis. A small number of records (trading days) were inaccessible and thus are not reported.

We start with brief descriptive statistics for the companies in our sample. We examine daily returns, volatility, autocorrelation, price dispersion, and trading volume.

\footnotetext{
${ }^{9}$ In the second Harlem corner, Vanderbilt was so furious at the short sellers that he was reported planning to drive the stock price to $\$ 1,000$. But he dropped his plan after leaning that it would bankrupt almost all brokerage firms on the street. See Clews (1888), chapter 34.
} 
We conduct this analysis for the pre-corner period, as well as in two corner sub-periods: corner period one - ten days before the corner to the corner date, and corner period two the day after the corner date to ten days following it. We present descriptive statistics for the returns for these periods in Table 2. ${ }^{10}$ Notice that there is a significant increase in returns during corner period one (3.3\%) as compared to the pre-corner period $(0.4 \%)$, and a subsequent decline in returns in corner period two (-2.9\%). One notable example is the Northwestern market corner - in the first corner sub-period daily returns were $9.3 \%$ on average, while in the post-corner period the average daily return was $-12 \%$. The return is continuously compounded for the duration of the corner period and is computed using the closing price.

There is a significant increase in the volatility of returns in both corner periods (6.6\% for corner period one, and 6.3\% for corner period two) as compared with the precorner period (2.9\%). Another indicator of interest is the increased price dispersion (7.5\% for corner period one, and 4\% for corner period two as compared to the periods before the corner 2.9\%). Price dispersion is defined as the daily spread between high and low as a percentage of the close price. The evidence on the impact of the market corner on price dispersion is consistent with the hypothesis that there exists significant private information trading in the run-up to the corner - as a result the price dispersion increases in the first period preceding the corner, while it substantially decreases in the period after the corner. For example in the corner of Northern Pacific price dispersion prior to the corner period is on average $1.9 \%$ daily. However, in the first corner sub-period, the price dispersion increases to $24.9 \%$ only to retreat to the low $3.2 \%$ following the corner.

Table 2 also shows a significant change in trading volume between the pre-corner and the corner periods. For example, the average daily share turnover has increased between pre-corner period to corner period one from 79,734 shares for RCA to more than 182,664, or from 37,645 to 119,263 for Northern Pacific, or from 7,602 to 14,407 for the second Erie corner. Even more spectacular was the dry-up of liquidity after the corner date for some stocks, e.g. a decrease from 119,263 shares in corner period one to 980 shares in corner period two for Northern Pacific. Figure 1 provides graphic plots of changing liquidity (we use cumulative abnormal trading volume as a proxy). The abnormal trading volume is defined as the difference between daily volume in the corner period and average

\footnotetext{
${ }^{10}$ The pre-corner periods have unequal length. See Table 2 for the precise length of each pre-corner period.
} 
daily trading volume in the pre-corner period. We standardize this variable with the standard deviation of the pre-corner period daily volume. In the figure, we have accumulated the trading volume across the corner period, i.e. at day t-10 (i.e. ten days prior to the corner date) we have plotted the abnormal trading volume at that date; at day t9 we have plotted the sum of the abnormal trading volume at days $t-10$ and $t-9$, etc.

A clear pattern of increased turnover and subsequent volume dry-up is displayed in Figure 1. However, the pattern of liquidity impact differs across successful and failed corners, apparently being stronger for the successful corners as compared to the failed ones. This is consistent with the hypothesis that market corners have a considerable impact on the liquidity of the cornered stock.

In Table 2, we analyze autocorrelation patterns. There seems to be a significant change in autocorrelation of returns between pre-corner and corner periods. In the first corner period we notice positive autocorrelation of $11.1 \%$, as compared with the second corner sub-period, where the autocorrelation is $-5.7 \%$. Both of these correlations are higher in absolute terms than the pre-corner autocorrelation of $-1 \%$. If autocorrelation is to be considered a proxy for the presence of private information trading conditional on high trading volume, we indeed witness an unprecedented increase in the pre-corner period informed trading. Upon completion of the corner, autocorrelations decline to become negative in eight of the twelve corners for which we have available post-corner data. These results are consistent with the theoretical findings of Llorente, Michaely, Saar, and Wang (2002) on private information trading during the corner period and liquidity trading afterwards.

In Table 3 we record the abnormal standardized daily returns in the $[t-10, t+10]$ day event window around the corner date. ${ }^{11}$ Standardized abnormal return is defined as the daily stock return in the corner periods in excess of the average daily return in the precorner period, scaled by the standard deviation of the pre-corner daily return (both the standard deviation and the mean for the pre-corner period are shown in Table 2). Notice that the mean of the abnormal standardized return is usually positive in the $[t-10, t]$ period, and negative in the $[t+1, t+10]$ period. This effect is more pronounced for successful corners as compared to failed ones. The two types of corners differ most significantly on

\footnotetext{
${ }^{11}$ We have attempted to collect a comprehensive data set for the entire event period however for five stocks we could not uncover all trading data. For two of them, Prairie du Chien and Northern Pacific we have missing data for seven and six trading days, respectively.
} 
the day of the corner with successful corners recording an average gain of 7.6 standard deviations above the pre-corner mean and failed corners recording a loss of 3.3 standard deviations below the pre-corner average. For both successful and failed corners abnormal standardized returns following the corner are negative, but more so for successful corners. We display this pattern by presenting the cumulative abnormal returns in the event period in Figure 2. Clearly there is an increase in the returns around the corner date for both successful and failed corners.

In Table 4 we present a comparison of successful and failed corners. The comparison is on standardized abnormal returns, trading volume, price dispersion, and excess return. The daily excess return is defined as the residual of the Black version of the CAPM model within the corner period, where the CAPM coefficients have been estimated from the pre-corner period. The reason we use the Black version of the CAPM is the lack of availability of a risk free rate for most of the periods considered. The average daily excess return data is presented only for Northern Pacific, Stutz Motor, Piggly Wiggly, RCA (successful corners) and silver futures (failed corner), since market data on the precorner period is not available for the other stocks. In particular we have retrieved the residuals from the following regression: $R_{i, t}=\alpha+\beta R_{m, t}+\varepsilon_{t}$, estimated from the precorner period, where $\mathrm{R}_{\mathrm{i}}$ is the company/ security i return, and $\mathrm{R}_{\mathrm{m}}$ is the market return. ${ }^{12} \mathrm{In}$ Table 4 we present t-statistics, based on a regression of the corresponding variable on a constant, where we use the Newey-West correction to address autocorrelation-in-residuals concerns.

In the period $[t-10, t]$ there is a significant increase of standardized abnormal returns of successful corners, 1.5 standard deviations above the pre-corner period. The increase has a positive sign for failed corners too. However, it is not statistically significant. After the corner date, strikingly, the successful corner stocks give back all abnormal return gains. Failed corners follow that pattern of post-corner negative returns, too, but the drop is less dramatic. A similar pattern is observed when one uses average daily excess returns: average daily excess returns were positive for the $[t-10, t]$ period for

\footnotetext{
${ }^{12}$ For Northern Pacific we use as market return and volume the daily return and volume for the Dow Jones Transports/Rails index. For Stutz Motor, Piggly Wiggly, RCA, and the silver futures on COMEX, we have used the daily market return and volume of the Dow Jones Industrial Average index.
} 
both successful and failed stocks. ${ }^{13}$ In the period $[t+1, t+10]$ the returns declined for both successful and failed corners.

Before the corner date, there is a significant rise in the abnormal volume of successful corner stocks, 0.88 standard deviations above the pre-corner average daily volumes. We observe the same result for failed corner stocks, but by half that magnitude. Strikingly, after the corner date we observe a sharp fall in trading volume, especially for successful corner stocks. Price dispersion also increased substantially before the corner especially for successful corner stocks, by 8.4\%. A similar increase is observed for failed corner stocks, but by much less, 2.9\%. The price dispersion decreased following the corner for successful corners (4.8\%), but it increased slightly for failed corners (3.3\%).

The above findings are also illustrated in Figures 3 and 4. In the two figures, there is a distinct difference between the patterns followed by successful and failed corner stocks. The successful corner stocks have higher daily price dispersion compared to the failed ones, reaching $36.1 \%$ on the date of the corner (for failed corners the price dispersion is 5.5\%) in Figure 3. The large price dispersion in the case of successful corners is indicative of the presence of private information trading and it reflects the volatile nature of market corners. The cumulative excess returns for successful corners peaked at the day of the corner to $53 \%$ above the pre-corner market return while returns for the failed corner are relatively flat at $6 \%$ on the corner date in Figure 4.

In Table 5 we present daily market returns in the period $[t-10, t+10]$ around the corner date. For Harlem, Prairie du Chien, Michigan Southern, Erie, Northwestern, and American Gold Coin we use as the market return the return on the equally weighted stocks returns, which was hand-collected from the Financial Affairs section of the New York Times for the corresponding time period. At the time, the companies included in that section were predominantly railroads. For Northern Pacific we use the Dow Jones Transports/ Rails Index. For Stutz Motor, Piggly Wiggly, and RCA we use the Dow Jones Industrials index. For the silver corner, we use the Dow Jones Industrial Average Index. Daily returns are presented in percentage value.

Results on market return are mixed. On average, the days following the corner had some of the largest decreases in returns. This spillover effect of the corner on the market return is perhaps due to the fact that short-sellers pressed for liquidity might start a fire sale

\footnotetext{
${ }^{13}$ However, a cautious interpretation of the failed corners is in order, since it is based only on the silver futures market corner.
} 
of their portfolios thus causing an overall decline of market returns. The effect seems to be transient since the market generally rebounded by the fourth day after the corner. Furthermore, we could see a pronounced increase in market volatility in the $[t-1, t+1]$ period around the corner date. This increase is more pronounced for successful corner stocks as compared to failed corner stocks.

The results from Table 5 are further illustrated in Figure 5 where we have presented the cumulative market return around the corner date. As discussed above the impact of successful corners on market returns seems to be transient. However, the impact of failed corners on market returns seems to be more pronounced.

In Table 6 we compute the average daily volatility for the pre-corner period, corner sub-period one, and corner sub-period two. The "open-close” volatility is defined as the volatility of $\ln \left(\right.$ Open $_{t} /$ Close $\left._{t}\right)$ prices, i.e. a proxy for the intra-day volatility of returns and arrival of new information in the market. The "close-open" volatility is defined as the volatility of $\ln \left(\right.$ Close $_{t-1} /$ Open $\left._{t}\right)$, or the volatility of the between-day returns. In Panel B we present t-tests of the null hypothesis of equality of volatility of various pairs of successful corners, (1) through (6). Opening price quotations are not available for the American Gold Coin corner.

We notice that there was much higher open-close (or intra-day) volatility for successful corners, in corner periods one (7.6\%) and two (5.5\%), as compared to the precorner period (2.5\%). A t-test of equality between pre-corner period and corner period one for successful corners' intra-day volatility reveals that they were statistically significantly different (p-value of 0.03). A similar t-test of equality between the pre-corner period and corner period two reveals that the difference was significantly different as well (p-value of 0.06). An increase in the open-close volatility in the corner periods is also observed for failed stocks, but by a lower magnitude. Intra-day volatility exceeded between-day volatility for successful stocks, in the pre-corner period and corner period one. This supports the hypothesis that intra-day price discovery had higher impact as compared to between-day price discovery in the pre-corner period and corner sub-period one. A t-test of equality of the average within-day and between-day volatility in corner period one shows that they were statistically significantly different (p-value 0.03). However, the between-day volatility for successful corners for corner period two (10\%) exceeded the intra-day volatility for the pre-corner period (2\%) and for corner period one (2.3\%). 
In Table 7, we present a test of the dynamic return-trading volume relationship in the corner period. We use the theoretical implications of Llorente et al. (2002), running the following regression:

$$
R_{i, t+1}=C_{0}+C_{1} R_{i, t}+C_{2} R_{i, t} V_{i, t}+C_{3} R_{i, t} V_{i, t} D_{i}+\varepsilon_{i, t+1},
$$

where $i$ indexes the corresponding company/security from our sample, $R_{i}$ is the continuously compounded return based on the closing price, $\mathrm{V}_{\mathrm{i}}$ is the natural logarithm of the total number of shares traded, and $D_{i}$ is a dummy variable with value 1 in the $[t-10, t]$ period around the corner date, $\mathrm{t}^{14}$ In their formulation, Llorente et al. (2002) ascertain that conditional on high trading volume, positive $\mathrm{C}_{2}$ coefficients are evidence of private information trading in the market. To adapt their framework to our analysis we test whether the $C_{2}$ coefficient is increased in the $[t-10, t]$ period. Thus, we are interested in testing whether the coefficient $\left(\mathrm{C}_{3}\right)$ of the interaction term, $R_{i, t} V_{i, t} D$, has a positive sign. If indeed private information trading was prevalent in the first corner period, then we would expect that the $\mathrm{C}_{3}$ coefficient would be positive and significant. ${ }^{15}$ We explore the analysis of our hypothesis for each of the twelve corner stocks and one corner commodity (silver futures contracts). We find statistically weak evidence of informed trading in the period [t10, $t$ ]: twelve of the thirteen $C_{3}$ coefficients are positive; however only four of them are significant. Informed trading around corner dates appears stronger for successful corners (higher average $\mathrm{C}_{3}$ and $\mathrm{R}^{2}$ ). In unreported results we find that these conclusions are robust to different period lengths, $[\mathrm{t}-5, \mathrm{t}]$, and $[\mathrm{t}-20, \mathrm{t}]$. The results from Table 7 are also consistent with the autocorrelation results presented in Table 2.

We are mindful of the limitations of the above test of private information trading: even though individual $\mathrm{C}_{3}$ coefficients are for the most part positive, they are generally insignificant. Perhaps this is due to the small sample we use in individual regressions as can be seen in Table 7. To mitigate this constraint, we estimate a pooled regression, where

\footnotetext{
${ }^{14}$ In their work, Llorente et al. (2002) use a measure of turnover, defined as the logarithm of the total number of shares traded scaled by the total number of shares outstanding. They further detrend this variable with a 200-days moving average. Given the data source limitations we faced, we could not replicate their proxy for trading volume - the total number of shares outstanding is not available for the stocks in our sample, and the data is available only for 60-100 days around the market corner. We note though that our proxy - logarithm of the total number of shares traded has the same time-series behavior if we assume that there is no change in the total number of shares outstanding within the corner period. Moreover, Llorente et al. (2002) show that the empirical implications of their theoretical result hold for total trading volume. Thus we use the logarithm of total trading volume.

${ }^{15}$ Here, price manipulation can be viewed as a special case of private information trading in which the manipulator controls a large float of shares and determines the timing of the corner.
} 
we have restricted only the coefficient $\mathrm{C}_{3}$ to be the same for all stocks/commodities while allowing the other coefficients to vary (introducing fixed effects for $C_{0}, C_{1}$, and $C_{2}$ ), an approach which allows us to test whether the imposed constraint on $\mathrm{C}_{3}$ is a true one.

$$
R_{i, t+1}=\sum_{i=1}^{15} C_{i, 0}+\sum_{i=1}^{15} C_{i, 1} R_{i, t}+\sum_{i=1}^{15} C_{i, 2} R_{i, t} V_{i, t}+C_{3} R_{i, t} V_{i, t} D_{i}+\varepsilon_{i, t+1}
$$

The estimates of $\mathrm{C}_{3}$ from the pooled regression are reported in Table 7 . Both successful and failed corners exhibit positive, statistically significant $C_{3}$ coefficients. When we pool all stocks/ commodities and perform the regression, the result is again a positive and highly statistically significant $C_{3}$ coefficient of 0.04 with a t-statistic of 4.11 . We interpret this as supporting our hypothesis of private information trading prior to the market corner. The presence of private information trading is consistent with the conjecture that the manipulator has more information on his holdings as well as his intended corner date.

\section{Concluding Remarks}

This paper investigates price and trading volume patterns around some well known stock market corners in US history. The analyses are based on a hand-collected new dataset of price and trading volume reported in the New York Times and Wall Street Journal from 1863-1928. We present strong evidence that large investors and corporate insiders possess market power that allows them to manipulate market price. Our results show that market corners as a result of manipulation tend to increase market volatility and could have an adverse price impact on other assets. We demonstrate that the presence of large investors makes it extremely risky for short sellers to arbitrage mispricing in the stock market. This creates severe limits to arbitrage in the stock market that tends to impede market efficiency. It can create a situation when there can be overpricing but arbitrageurs are unwilling to establish a short position because of manipulation risk (in addition to fundamental and noise trader risk). Therefore, regulators and exchanges need to be concerned about ensuring that corners do not take place since they are accompanied by severe price distortions.

An important question for future research is how corners occur in a rational expectations setting. The historical evidence shows that corners occurred repeatedly until they were outlawed. This suggests that they were profitable for those causing them and that those undertaking short sales lost money when a corner occurred. Why would the short 
sellers be willing to bear the risks of such a loss? Presumably the reason is that the rest of the time when the market is not cornered they make sufficient profits from their short sales to at least make up for the corners. This will only happen if the market is fairly inefficient in the sense that arbitrage does not lead prices to fully reflect fundamentals. Interestingly the possibility of corners can increase the price of stocks before the corner attempt. Those who actually hold the stock when the corner takes place are able to sell at a high price and this will be reflected beforehand. If corners involve sufficient risk, however, then the price effect may be negative relative to an equilibrium with no corners. 


\section{References}

Aggarwal, R. and G. Wu, 2003, “Stock Market Manipulation - Theory and Evidence,” working paper, University of Michigan.

Allen, F., and D. Gale, 1992, “Stock Price Manipulation,” Review of Financial Studies, Vol. 5: 503-529.

Allen, F., and G. Gorton, 1992, "Stock Price Manipulation, Market Microstructure and Asymmetric Information,” European Economic Review, Vol. 36: 624-630.

Bagnoli, M., and B.L. Lipman, 1996, "Stock Price Manipulation through Takeover Bids,” RAND Journal of Economics, Vol. 27: 124-147.

Benabou, R., and G. Laroque, 1992, "Using Privileged Information to Manipulate Markets: Insiders, Gurus and Credibility,” Quarterly Journal of Economics, Vol. 105: 921-958.

Brooks, J., 1969, Once in Golconda: A True Drama of Wall Street 1920-1938, New York: Harper \& Row.

Chakraborty, A., and B. Yilmaz, 2003, “Informed Manipulation,” Journal of Economic Theory, forthcoming.

Chakraborty, A. and B. Yilmaz, 2004, “Manipulation in Market Order Models,” Journal of Financial Markets, forthcoming.

Chancellor, E., 2000, Devil Take the Hindmost: A History of Financial Speculation, New York: Plume Books.

Cherian, J. A., and R. A. Jarrow, 1995, “Market Manipulation,” Chapter 20 in NorthHolland Handbooks of Operations Research and Management Science: Finance (Volume 9) edited by R. A. Jarrow, V. Maksimovic and W. T. Ziemba, New York: Elsevier, 611-630.

Clews, H., 1888, Twenty Eight Years in Wall Street, New York: Irving Publishing Co.

Flynn, J.T., 1934, Security Speculation: Its Economic Effects, New York: Harcourt Brace.

Felixson, K., and A. Pelli, 1999, "Day End Returns - Stock Price Manipulation,” Journal of Multinational Financial Management, Vol. 9: 95-127.

Galbraith, A. J., 1972, The Great Crash, 1929, Boston: Houghton Mifflin Company.

Goetzmann, W., and P. Jorion, 1999, “Global Stock Markets in the Twentieth Century”, Journal of Finance, Vol. 54: 953-980.

Goldstein, I., and A. Guembel, 2003, “Manipulation, the Allocational Role of Prices and Production Externalities,” working paper, Duke University.

Gordon, J. 1999, The Great Game: The Emergence of Wall Street as a World Power: 1653-2000, New York: Touchstone.

Hart, O. D., 1977, “On the Profitability of Speculation,” Quarterly Journal of Economics, Vol. 90: 579-596.

Hart, O. D., and D. Kreps, 1986, “Price Destabilizing Speculation,” Journal of Political Economy, Vol. 94: 927 - 952. 
Jarrow, R. A., 1992, "Market Manipulation, Bubbles, Corners, and Short Squeezes," Journal of Financial and Quantitative Analysts, Vol. 27: 311-336.

Jarrow, R. A., 1994, “Derivative Security Markets, Market Manipulation, and Option Pricing Theory,” Journal of Financial and Quantitative Analysts, Vol. 29: 241-261.

Jegadeesh, N., 1993, “Treasury Auction Bids and the Salomon Squeeze,” Journal of Finance, Vol. 48: 1403-1419.

Jiang, G., P. Mahoney, and J. Mei, 2004, "Market Manipulation: A Comprehensive Study of Stock Pools,” Journal of Financial Economics, forthcoming.

Jones, C, and O. Lamont, 2002, “Short Sale Constraints and Stock Returns,” Journal of Financial Economics, Vol. 47: 207 -239.

Jordan, B., and S. Jordan, 1996, "Salomon Brothers and the May 1991 Treasury Auction: Analysis of a Market Corner,” Journal of Banking and Finance, Vol. 20: 2540.

Khwaja, A., and A. Mian, 2004, "Unchecked Intermediaries: Price Manipulation in an Emerging Stock Market,” Journal of Financial Economics, forthcoming.

Krugman, P., 1996, “How Copper Came a Cropper Sumitomo's Robber-baron Tactics Make the Case for Regulation,” http://web.mit.edu/krugman/www/copper.html.

Kumar, P., and D. J. Seppi, 1992, “Futures Manipulation with Cash Settlement,” Journal of Finance, Vol. 47: 1485-1502.

Kyle, A., and W. Xiong, 2001, "Contagion as a Wealth Effect," Journal of Finance, Vol. 56: 1401-1440.

Llorente, G., R. Michaely, G. Saar, and J. Wang, 2002, “Dynamic Volume-Return Relation of Individual Stocks,” Review of Financial Studies, Vol.15: 1005 - 1047.

Mahoney, P., 1999, “The Stock Pools and the Securities Exchange Act,” Journal of Financial Economics, Vol. 51: 343-369.

Mei, J., G. Wu, and C. Zhou, 2004, "Behavior Based Manipulation - Theory and Prosecution Evidence,” working paper, New York University.

Merrick J., N. Y. Naik, and P. K. Yadav, 2004, “Strategic Trading Behaviour and Price Distortion in a Manipulated Market: Anatomy of a Squeeze,” Journal of Financial Economics, forthcoming.

Pirrong, S., 1993, "Manipulation of the Commodity Futures Market Delivery Process,” Journal of Business, Vol. 66: 335-369.

Securities and Exchange Commission, 1959, A 25 Year Summary of the Activities of the Securities and Exchange Commission, Washington, D.C.

Sharp, R., 1989, The Lore and Legends of Wall Street, Homewood, Ill.: Dow JonesIrwin.

Sobel, R., 1865, The Big Board, New York: Free Press.

Stedman, E.C., 1905, The New York Stock Exchange; its History, its Contribution to National Prosperity, and its Relation to American Finance at the Outset of the Twentieth Century, New York: Greenwood Press. 
Thomas, D., 1989, The Plungers and the Peacocks: An Update of the Classic History of the Stock Market, New York: William Morrow and Company, Inc.

Twentieth Century Fund, 1935, Security Markets, New York: H. Wolff.

Van Bommel, J., 2003, “Rumors,” Journal of Finance, Vol. 58: 1499 - 1520.

Vila, J.L., 1987, “The Role of Information in the Manipulation of Futures Markets,” Working Paper 87-26, CARESS, University of Pennsylvania.

Vila, J.L., 1989, “Simple Games of Market Manipulation,” Economics Letters, 29, 2126.

Vitale, P., 2000, "Speculative Noise Trading and Manipulation in the Foreign Exchange Market,” Journal of International Money and Finance, Vol. 19: 689-712.

Wycoff, R.D., 1968, Wall Street Ventures and Adventures, New York: Greenwood Press.

Wyckoff, P., 1972, Wall Street and the Stock Market, Philadelphia: Chilton Book Company. 


\section{Table 1: The Sample of Corners}

We define the corner date as the date when shares that were sold short are called by the manipulator. Corner dates have been established as found in the references, in particular, Clews (1888), Flynn (1934), Thomas (1989), and Wycoff $(1968,1972)$. Alongside the corner date we have characterized the outcome of the corner as successful or failed. For the Stutz Motor Company and the Piggly-Wiggly Company, we do not have observations after the corner date, due to the institutional halt in trading for both stocks, shortly prior to the corner date. Instead, for these stocks we report the results only for the period until the end of trading.

\begin{tabular}{lcc}
\hline \multicolumn{1}{c}{ Company Name } & Corner Date & Corner Status \\
\hline Harlem 1863 & & \\
\multicolumn{1}{c}{1864} & $08 / 24 / 1863$ & Successful \\
Prairie du Chien & $05 / 17 / 1864$ & Successful \\
Michigan Southern & $11 / 07 / 1865$ & Successful \\
Erie Railroads & $04 / 04 / 1866$ & Successful \\
$\quad$ March - 1868 & & \\
$\quad$ October - 1868 & $03 / 10 / 1868$ & Failed \\
American Gold Coin & $11 / 16 / 1868$ & Successful \\
Erie Railroads, 1872 & $09 / 24 / 1869$ & Failed \\
Northwestern & $09 / 17 / 1872$ & Failed \\
Northern Pacific & $11 / 23 / 1872$ & Successful \\
Stutz Motor & $05 / 09 / 1901$ & Successful \\
Piggly Wiggly & $04 / 26 / 1920$ & Successful \\
RCA & $03 / 20 / 1923$ & Successful \\
Silver “Corner”, 1980 & $03 / 13 / 1928$ & Successful \\
\hline
\end{tabular}




\section{Table 2: The Return, Price Dispersion, and Volume around Corners}

The corner period is defined as [t-10, $\mathrm{t}+10]$ days around the corner date, $\mathrm{t}$, a total of twenty-one days, including the corner date. The number of observations reflects the number of non-missing daily return observations. Return is defined as the continuously compounded return computed from the close price. Share volume is defined as the total number of shares traded in the corresponding trading day. Autocorrelation refers to the autocorrelation of returns computed within the corresponding period (differs across panels $A, B$, and $C$ ), $\rho_{t}=\operatorname{corr}\left(R_{t}, R_{t-1}\right)$. Price dispersion refers to the difference between high and low, scaled with the close price for each trading day. For Stutz Motor, we have defined the corner period starting date as 10 days prior to the decision to halt the trading of the company stock, since its corner date is after the official halt of trading. The pre-corner period is defined as the period since data is available through eleven days before the corner date. The first corner sub-period is defined as the period ten days before the corner date until the corner date. The second corner sub-period is defined as the period from the first day following the corner to the tenth day following the corner date.

\begin{tabular}{|c|c|c|c|c|c|c|c|c|}
\hline \multicolumn{9}{|c|}{ Panel A: Pre-corner Period } \\
\hline & \multirow[b]{2}{*}{$\mathbf{N}$} & \multicolumn{2}{|c|}{ Daily Return } & \multicolumn{2}{|c|}{ Daily Price Dispersion } & \multicolumn{2}{|c|}{ Daily Shares Traded } & \multirow{2}{*}{$\begin{array}{c}\begin{array}{c}\text { Daily } \\
\text { Autocorr. }\end{array} \\
\rho_{1, \mathrm{cs}}\end{array}$} \\
\hline & & Mean & Std. Dev & Mean (\%) & $\begin{array}{c}\text { Std. Dev } \\
(\%)\end{array}$ & Mean & Std. Dev & \\
\hline Harlem, 1863 & 58 & 0.003 & 0.058 & 4.0 & 3.6 & 10,415 & 7,656 & -0.206 \\
\hline Harlem, 1864 & 53 & 0.010 & 0.054 & 5.0 & 3.9 & 10,536 & 8,171 & -0.173 \\
\hline Prairie du Chien & 34 & 0.006 & 0.027 & 2.4 & 1.8 & 1,471 & 1,372 & 0.326 \\
\hline Michigan Southern & 41 & 0.004 & 0.019 & 2.6 & 1.7 & 12,070 & 4,966 & -0.430 \\
\hline Erie, 03-1868 & 39 & -0.002 & 0.016 & 1.8 & 1.3 & 19,791 & 8,748 & 0.022 \\
\hline Erie, $11-1868$ & 55 & -0.002 & 0.028 & 2.8 & 1.5 & 7,602 & 7,571 & 0.200 \\
\hline Gold Coin, 1869 & 48 & 0.000 & 0.005 & - & - & - & - & 0.140 \\
\hline Erie, 1872 & 43 & -0.002 & 0.026 & 3.0 & 1.9 & 19,647 & 13,609 & -0.144 \\
\hline Northwestern & 40 & 0.001 & 0.029 & 2.9 & 2.4 & 20,283 & 18,209 & -0.175 \\
\hline Northern Pacific & 56 & 0.005 & 0.013 & 1.9 & 1.2 & 37,645 & 33,841 & -0.059 \\
\hline Stutz Motor & 56 & 0.011 & 0.039 & 3.1 & 3.0 & 1,009 & 971 & 0.087 \\
\hline Piggly Wiggly & 61 & 0.006 & 0.034 & 2.2 & 1.8 & 2,405 & 2,385 & -0.232 \\
\hline RCA & 46 & 0.001 & 0.023 & 3.2 & 1.5 & 79,734 & 48,919 & -0.036 \\
\hline Silver “Corner”, 1980 & 40 & 0.018 & 0.035 & 2.3 & 2.2 & 7,125 & 5,069 & 0.542 \\
\hline Mean & & 0.004 & 0.029 & 2.9 & 2.1 & & & -0.010 \\
\hline
\end{tabular}


Table 2. (continued)

Panel B: Corner-Period One, $[t-10, t]$

\begin{tabular}{lccccccc}
\hline & \multicolumn{2}{c}{ Daily Return } & \multicolumn{2}{c}{ Daily Price Dispersion } & \multicolumn{2}{c}{ Daily Shares Traded } & Daily Autocorr. \\
\cline { 2 - 7 } & Mean & Std. Dev & $\begin{array}{c}\text { Mean } \\
(\%)\end{array}$ & $\begin{array}{c}\text { Std. Dev } \\
\mathbf{( \% )}\end{array}$ & Mean & Std. Dev & $\rho_{\mathbf{1 , c s}}$ \\
\hline Harlem, 1863 & 0.019 & 0.039 & 3.2 & 1.7 & 8,459 & 3,902 & 0.131 \\
Harlem, 1864 & 0.018 & 0.029 & 1.0 & 1.4 & 773 & 641 & -0.194 \\
Prairie du Chien & 0.035 & 0.109 & 16.7 & 14.7 & 4,287 & 1,698 & 0.167 \\
Michigan Southern & 0.011 & 0.014 & 5.1 & 3.6 & 14,491 & 7,693 & 0.264 \\
Erie, 03-1868 & 0.009 & 0.029 & 4.2 & 2.3 & 24,462 & 13,966 & 0.026 \\
Erie, 11-1868 & 0.021 & 0.077 & 5.1 & 2.8 & 14,402 & 17,708 & 0.713 \\
Gold Coin, 1869 & -0.002 & 0.024 & - & - & - & - & -0.285 \\
Erie, 1872 & 0.006 & 0.023 & 4.4 & 3.1 & 23,600 & 13,665 & -0.298 \\
Northwestern & 0.093 & 0.161 & 11.4 & 18.3 & 7,536 & 5,385 & 0.525 \\
Northern Pacific & 0.122 & 0.246 & 24.9 & 49.2 & 119,263 & 112,599 & 0.122 \\
Stutz Motor & 0.066 & 0.048 & 7.3 & 2.7 & 3,585 & 1,879 & -0.243 \\
Piggly Wiggly & 0.005 & 0.066 & 8.7 & 17.0 & 3,982 & 6,357 & -0.119 \\
RCA & 0.036 & 0.050 & 4.8 & 3.4 & 182,664 & 119,044 & 0.803 \\
Silver “Corner”, 1980 & 0.023 & 0.012 & 0.0 & 0.0 & 9,347 & 5,129 & -0.059 \\
Mean & $\mathbf{0 . 0 3 3}$ & $\mathbf{0 . 0 6 6}$ & $\mathbf{7 . 5}$ & $\mathbf{9 . 2}$ & & & $\mathbf{0 . 1 1 1}$ \\
\hline
\end{tabular}

Panel C: Corner-Period Two, $[t+1, t+10]$

\begin{tabular}{lccccccc}
\hline & \multicolumn{2}{c}{ Daily Return } & \multicolumn{2}{c}{ Daily Price Dispersion } & \multicolumn{2}{c}{ Daily Shares Traded } & Daily Autocorr. \\
\cline { 2 - 7 } & Mean & Std. Dev & $\begin{array}{c}\text { Mean } \\
(\%)\end{array}$ & $\begin{array}{c}\text { Std. Dev } \\
(\mathbf{\%})\end{array}$ & Mean & Std. Dev & $\rho_{1, c s}$ \\
\hline Harlem, 1863 & -0.032 & 0.035 & 4.8 & 5.0 & 6,681 & 2,819 & 0.672 \\
Harlem, 1864 & 0.000 & 0.007 & 0.3 & 0.4 & 375 & 199 & -0.412 \\
Prairie du Chien & -0.026 & 0.110 & 2.9 & 4.8 & 620 & 444 & -0.356 \\
Michigan Southern & -0.011 & 0.019 & 3.5 & 7.1 & 6,600 & 4,787 & 0.062 \\
Erie, 03-1868 & -0.004 & 0.028 & 3.0 & 1.6 & 16,003 & 8,017 & 0.394 \\
Erie, 11-1868 & -0.035 & 0.019 & 11.9 & 11.8 & 7,398 & 7,843 & -0.223 \\
Gold Coin, 1869 & -0.002 & 0.007 & - & - & - & - & -0.086 \\
Erie, 1872 & -0.006 & 0.031 & 6.1 & 3.6 & 20,236 & 14,063 & -0.064 \\
Northwestern & -0.121 & 0.186 & 5.2 & 10.7 & 2,335 & 2,146 & 0.620 \\
Northern Pacific & -0.099 & 0.258 & 3.2 & 2.6 & 980 & 646 & -0.958 \\
Stutz Motor & - & - & - & - & - & - & - \\
Piggly Wiggly & - & - & - & - & - & - & - \\
RCA & 0.009 & 0.047 & 6.9 & 3.0 & 99,690 & 71,470 & -0.026 \\
Silver “Corner”, 1980 & -0.019 & 0.014 & 0.7 & 1.1 & 5,097 & 4,036 & -0.309 \\
Mean & $\mathbf{- 0 . 0 2 9}$ & $\mathbf{0 . 0 6 3}$ & $\mathbf{4 . 0}$ & $\mathbf{4 . 3}$ & & & $\mathbf{- 0 . 0 5 7}$ \\
\hline
\end{tabular}


Table 3: Abnormal Standardized Returns for Corner Stocks

Abnormal standardized return is defined as the daily return in the corner period in excess of the average daily return in the pre-corner period, standardized with the standard deviation of the pre-corner daily return, shown in Table 2. Day zero (i.e. t) is the day of the corner. If we could not find data from the New York Times and Wall Street Journal for the corresponding day (due to unreadable records or missing issues of the source), we do not report the daily return figure. For Stutz Motor, day zero is defined as the day when the NYSE halted trading in that stock. For the Stutz Motor and Piggly Wiggly corners, trading was halted prior or upon the corner occurrence.

\begin{tabular}{|c|c|c|c|c|c|c|c|c|c|c|c|c|c|c|c|c|c|c|c|c|c|}
\hline & \multicolumn{21}{|c|}{ Dayt } \\
\hline & -10 & -9 & -8 & -7 & -6 & -5 & -4 & -3 & -2 & -1 & 0 & 1 & 2 & 3 & 4 & 5 & 6 & 7 & 8 & 9 & 10 \\
\hline \multicolumn{22}{|l|}{ Successful Corners } \\
\hline Harlem, 1863 & 0.18 & -0.08 & 0.12 & 1.15 & 1.15 & -1.14 & -0.49 & 0.28 & 1.10 & 0.35 & 0.34 & -0.54 & -0.25 & -0.34 & -0.17 & 0.18 & -0.28 & -0.35 & -0.87 & -1.90 & -1.52 \\
\hline Harlem, 1864 & -0.22 & -0.84 & 0.64 & 0.21 & -0.18 & 1.40 & 0.17 & 0.44 & 0.15 & 0.15 & -0.18 & -0.18 & -0.45 & 0.08 & -0.12 & -0.18 & -0.18 & -0.25 & -0.12 & -0.25 & -0.12 \\
\hline Prairie du Chien & -0.20 & - & - & 2.36 & -0.57 & 3.81 & 3.21 & 6.15 & - & - & -7.24 & 1.84 & -7.90 & -5.45 & 5.05 & - & - & - & -1.66 & 0.17 & -0.20 \\
\hline Michigan Southern & 0.12 & -0.62 & -0.21 & 0.94 & -0.37 & 0.36 & - & - & 1.94 & 0.95 & 0.17 & -2.53 & -2.97 & 0.29 & -0.87 & -0.54 & 0.21 & -0.38 & -0.29 & -0.63 & -0.38 \\
\hline Erie, 11-1868 & -1.15 & 0.19 & 0.42 & -0.14 & -0.26 & -0.03 & -0.38 & -1.10 & -1.14 & 4.50 & 8.17 & -1.62 & -1.41 & -1.18 & -1.54 & -0.76 & 0.40 & -1.53 & -1.84 & - & - \\
\hline Northwestern & 0.79 & -0.32 & -0.17 & -0.12 & 0.19 & 0.08 & -0.22 & 4.27 & 1.73 & 17.03 & 11.29 & -4.78 & -12.16 & -16.90 & - & - & 0.08 & 1.06 & -0.41 & -0.26 & 0.33 \\
\hline Northern Pacific & - & - & 2.78 & -0.03 & -0.83 & -4.00 & 0.16 & 10.61 & - & - & 52.25 & -57.74 & - & - & -5.14 & -6.00 & 0.18 & 3.77 & 3.08 & -0.59 & 0.60 \\
\hline Stutz Motor & 1.53 & 1.64 & 0.30 & 1.89 & 0.04 & 2.98 & 3.25 & -0.74 & 0.59 & 2.70 & 1.13 & - & - & - & - & - & - & - & - & - & - \\
\hline Piggly Wiggly & -0.33 & -0.24 & -0.33 & 0.66 & -1.04 & -0.43 & -0.34 & -4.70 & 1.88 & 0.64 & 3.65 & - & - & - & - & - & - & - & - & - & - \\
\hline RCA & 0.66 & 0.31 & -0.31 & -0.37 & 0.99 & 0.86 & -0.53 & 0.30 & 3.97 & 4.82 & 6.01 & 2.26 & 1.14 & -2.10 & -0.18 & -0.49 & -1.28 & 5.32 & -1.16 & -0.03 & -0.03 \\
\hline Mean & 0.2 & 0.0 & 0.4 & 0.7 & -0.1 & 0.4 & 0.5 & 1.7 & 1.3 & 3.9 & 7.6 & -7.9 & -3.4 & -3.7 & -0.4 & -1.3 & -0.1 & 1.1 & -0.4 & -0.5 & -0.2 \\
\hline \multirow[t]{3}{*}{ St. Dev. } & 0.8 & 0.8 & 1.0 & 0.9 & 0.7 & 2.2 & 1.5 & 4.6 & 1.5 & 5.6 & 16.5 & 20.3 & 4.8 & 6.2 & 3.0 & 2.3 & 0.6 & 2.5 & 1.5 & 0.7 & 0.7 \\
\hline & \multicolumn{21}{|c|}{ Dayt } \\
\hline & -10 & -9 & -8 & -7 & -6 & -5 & -4 & -3 & -2 & -1 & 0 & 1 & 2 & 3 & 4 & 5 & 6 & 7 & 8 & 9 & 10 \\
\hline \multicolumn{22}{|l|}{ Failed Corners } \\
\hline Erie, 03-1868 & 0.48 & -0.10 & -0.45 & -0.70 & 4.74 & 2.21 & -0.41 & 2.16 & 2.30 & -2.25 & -0.40 & 0.77 & 1.28 & -1.01 & -2.89 & -2.23 & -1.85 & 2.34 & 2.38 & -0.53 & 0.47 \\
\hline Gold, 1869 & 0.53 & 0.01 & 0.36 & 0.18 & 0.35 & 0.18 & 0.87 & 0.35 & 4.77 & 2.84 & -13.90 & -0.71 & -1.43 & -0.71 & 1.45 & -3.43 & 0.92 & 0.37 & -0.36 & 0.01 & -0.36 \\
\hline Erie, 1872 & 0.57 & 0.17 & -0.22 & -0.52 & 0.87 & -1.12 & 0.38 & 1.07 & 1.89 & -0.87 & 1.02 & 0.90 & -0.11 & -1.04 & -0.02 & 2.37 & -2.13 & -1.18 & -0.82 & 0.17 & 0.17 \\
\hline Silver “Corner”, 1980 & 0.37 & -0.94 & 0.13 & 0.33 & 0.31 & 0.28 & 0.26 & 0.24 & 0.22 & 0.20 & 0.18 & -1.25 & -1.27 & -1.29 & -1.31 & -1.33 & -0.21 & -0.97 & -1.56 & -0.41 & -1.38 \\
\hline Mean & 0.5 & -0.2 & 0.0 & -0.2 & 1.6 & 0.4 & 0.3 & 1.0 & 2.3 & 0.0 & -3.3 & -0.1 & -0.4 & -1.0 & -0.7 & -1.2 & -0.8 & 0.1 & -0.1 & -0.2 & -0.3 \\
\hline St. Dev. & 0.1 & 0.5 & 0.4 & 0.5 & 2.1 & 1.4 & 0.5 & 0.9 & 1.9 & 2.2 & 7.1 & 1.1 & 1.3 & 0.2 & 1.8 & 2.5 & 1.4 & 1.6 & 1.7 & 0.3 & 0.8 \\
\hline
\end{tabular}


Table 4: Successful vs. Failed Corner Stocks Using Standardized Abnormal Returns, Volumes, Price Dispersion, and Excess Returns and Volumes

Standardized abnormal return is defined as the daily return in the corner period in excess of the average daily return in the pre-corner period, divided by the standard deviation of the pre-corner daily return, shown in Table 2. We define similarly the standardized abnormal share volume. Price dispersion is the daily spread between high and low as a percentage from the close price for the corner stocks. The daily excess return and volume are defined as the residual of the Black version of the CAPM model within the corner period, where the CAPM coefficients have been estimated from the pre-corner period. The average daily excess return data is presented only for Northern Pacific, Stutz Motor, Piggly Wiggly, RCA (successful corners) and silver "corner" (failed corner), since market data on the pre-corner period is not available for the other stocks. In parentheses below the averages we present their t-statistics, based on a regression of the corresponding variable on a constant, where we have used the Newey-West correction for autocorrelation in residuals. Day zero (i.e. t) is the day of the corner.

\begin{tabular}{|c|c|c|c|c|}
\hline & \multicolumn{2}{|c|}{$\begin{array}{c}\text { Corner Period 1, } \\
{[\mathrm{t}-\mathbf{1 0}, \mathrm{t}]}\end{array}$} & \multicolumn{2}{|c|}{$\begin{array}{c}\text { Corner Period 2, } \\
{[t+1, t+10]}\end{array}$} \\
\hline & Successful & Failed & Successful & Failed \\
\hline $\begin{array}{c}\text { Average Daily Standardized Abnormal Return } \\
\text { T-stat }\end{array}$ & $\begin{array}{c}1.51 \\
(2.27)\end{array}$ & $\begin{array}{c}0.20 \\
(0.67)\end{array}$ & $\begin{array}{c}-1.76 \\
(-1.91)\end{array}$ & $\begin{array}{l}-0.45 \\
(-2.28)\end{array}$ \\
\hline $\begin{array}{c}\text { Average Daily Standardized Abnormal Volume } \\
\qquad \text { T-stat }\end{array}$ & $\begin{array}{c}0.88 \\
(2.76)\end{array}$ & $\begin{array}{c}0.42 \\
(1.80)\end{array}$ & $\begin{array}{l}-0.64 \\
(-4.31)\end{array}$ & $\begin{array}{l}-0.26 \\
(-1.20)\end{array}$ \\
\hline $\begin{array}{l}\text { Average Daily Price Dispersion (\%) } \\
\text { T-stat }\end{array}$ & $\begin{array}{l}8.4 \% \\
(4.05)\end{array}$ & $\begin{array}{l}2.9 \% \\
(3.57)\end{array}$ & $\begin{array}{l}4.8 \% \\
(4.56)\end{array}$ & $\begin{array}{l}3.3 \% \\
(3.43)\end{array}$ \\
\hline $\begin{array}{c}\text { Average Daily Excess Return } \\
\text { T-stat }\end{array}$ & $\begin{array}{c}0.05 \\
(2.04)\end{array}$ & $\begin{array}{c}0.01 \\
(2.15)\end{array}$ & $\begin{array}{l}-0.04 \\
(-0.86)\end{array}$ & $\begin{array}{c}-0.04 \\
(-11.48)\end{array}$ \\
\hline
\end{tabular}




\section{Table 5: Market Daily Return around Corner Dates}

We present the daily market returns in the period [t-10, t+10] of the corner date. For Harlem, Prairie du Chien, Michigan Southern, Erie, Northwestern, and American Gold Coin we use as market return the return on the equally weighted stocks returns hand collected from the Financial Affairs section of the New York Times, for the corresponding period. At the time, the companies included in that section were predominantly railroads. For Northern Pacific we use the Dow Jones Transports/ Rails Index. For Stutz Motor, Piggly Wiggly, and RCA we use the Dow Jones Industrials index. For the silver corner, we use the Dow Jones Industrial Average Index. Daily returns are presented in percentage value.

\begin{tabular}{|c|c|c|c|c|c|c|c|c|c|c|c|c|c|c|c|c|c|c|c|c|c|}
\hline \multirow[b]{3}{*}{ Successful Corners } & \multicolumn{21}{|c|}{ Day t } \\
\hline & -10 & -9 & -8 & -7 & -6 & -5 & -4 & -3 & -2 & -1 & 0 & 1 & 2 & 3 & 4 & 5 & 6 & 7 & 8 & 9 & 10 \\
\hline & \multicolumn{21}{|c|}{$\%$} \\
\hline Harlem, 1863 & -0.8 & 0.4 & 2.6 & 1.9 & 2.1 & -0.3 & -0.1 & 1.3 & -0.2 & 0.0 & 1.8 & 0.2 & -1.2 & -0.3 & 0.0 & 0.9 & -0.3 & -1.0 & -2.5 & -6.2 & 0.9 \\
\hline Harlem, 1864 & -2.0 & -2.0 & 2.0 & -0.1 & 2.3 & 1.3 & 1.2 & -0.7 & 1.3 & 3.1 & 0.1 & 1.9 & -2.4 & 0.1 & 1.8 & -0.9 & 0.5 & 0.5 & -0.5 & -0.7 & -0.1 \\
\hline Prairie du Chien, 1865 & 0.7 & -0.1 & 0.7 & 1.3 & 0.5 & -0.1 & -0.5 & 0.5 & -0.7 & 2.5 & 0.0 & -1.4 & 0.4 & -0.6 & -0.5 & -0.1 & 0.9 & 0.6 & 0.1 & 0.1 & 0.9 \\
\hline Michigan Southern, 1866 & 0.3 & -0.2 & -0.1 & 0.1 & 0.2 & -0.3 & -0.5 & -0.8 & 0.4 & 0.1 & 0.6 & -0.8 & 0.5 & 0.2 & 0.0 & 0.5 & 0.5 & 0.6 & 2.6 & -1.3 & 0.5 \\
\hline Erie, $11-1868$ & -2.4 & -3.0 & -2.5 & 3.5 & 0.0 & -0.8 & 0.2 & -0.8 & -0.5 & 3.5 & 0.7 & -1.6 & 1.3 & -0.7 & -0.3 & -0.5 & 1.4 & -0.7 & 0.6 & 1.3 & 0.0 \\
\hline Northwestern, 1872 & 2.0 & -0.3 & -0.4 & -0.2 & 0.7 & -0.3 & -0.4 & 1.4 & 0.8 & 3.3 & 0.9 & 0.9 & -5.1 & 0.7 & -0.1 & 0.1 & 0.1 & -0.1 & 0.1 & 0.5 & -0.8 \\
\hline Northern Pacific, 1901 & 0.7 & 1.7 & 0.6 & 1.3 & -0.1 & -1.3 & 0.3 & 0.9 & -0.5 & -4.8 & -7.7 & 6.3 & -0.4 & -4.8 & 2.1 & 1.0 & 2.2 & -0.1 & -1.2 & 0.7 & -0.2 \\
\hline Stutz Motor, 1920 & 0.5 & -0.7 & 0.3 & -0.3 & -2.5 & -2.4 & -3.6 & 1.3 & -1.8 & 0.3 & 1.5 & -0.8 & -1.7 & -1.7 & 0.4 & 0.5 & 0.3 & 0.1 & -0.3 & -0.8 & 1.4 \\
\hline Piggly Wiggly, 1923 & -0.5 & -0.2 & -0.6 & 0.4 & 0.5 & 0.5 & -0.5 & -0.8 & 0.9 & 0.4 & 0.0 & -0.1 & -0.1 & -1.1 & -0.7 & -0.9 & 0.7 & 0.4 & -0.7 & 0.0 & -1.2 \\
\hline RCA, 1928 & 0.4 & 0.0 & -0.1 & 0.5 & 1.2 & 0.9 & -1.0 & 0.4 & 1.5 & -0.5 & 1.5 & -0.5 & -0.6 & 0.9 & 0.9 & -0.3 & -0.2 & 0.8 & 0.8 & -0.1 & 0.9 \\
\hline Mean & -0.1 & -0.4 & 0.2 & 0.8 & 0.5 & -0.3 & -0.5 & 0.3 & 0.1 & 0.8 & -0.1 & 0.4 & -0.9 & -0.7 & 0.4 & 0.0 & 0.6 & 0.1 & -0.1 & -0.6 & 0.2 \\
\hline \multirow[t]{3}{*}{ St. Dev. } & 1.3 & 1.3 & 1.4 & 1.2 & 1.3 & 1.1 & 1.3 & 1.0 & 1.0 & 2.5 & 2.8 & 2.3 & 1.8 & 1.6 & 0.9 & 0.7 & 0.7 & 0.6 & 1.3 & 2.1 & 0.8 \\
\hline & \multicolumn{21}{|c|}{ Dayt } \\
\hline & -10 & -9 & -8 & -7 & -6 & -5 & -4 & -3 & -2 & -1 & 0 & 1 & 2 & 3 & 4 & 0 & 6 & 7 & 8 & 9 & 10 \\
\hline Failed Corners & \multicolumn{21}{|c|}{$\%$} \\
\hline Erie, 03-1868 & 0.7 & 0.5 & -0.2 & -0.9 & 1.0 & 0.5 & -0.1 & 0.1 & 2.9 & -0.2 & -4.1 & -0.3 & 0.4 & 0.2 & -0.5 & -1.5 & -0.1 & 0.7 & 0.6 & 0.0 & 0.0 \\
\hline Gold, 1869 & 0.2 & -0.2 & -0.4 & -0.6 & -1.4 & 0.7 & 0.3 & -0.8 & -2.5 & 0.3 & 0.4 & -1.0 & -3.8 & -4.5 & 1.7 & 1.2 & 2.2 & 0.1 & 0.2 & -0.2 & -0.1 \\
\hline Erie, 1872 & -0.5 & 0.1 & 0.0 & -0.1 & 0.4 & -0.6 & 0.0 & 0.5 & 0.5 & -0.3 & -1.7 & 0.2 & 0.1 & 0.5 & -0.1 & -0.1 & -0.2 & 0.0 & -0.3 & 0.8 & -0.2 \\
\hline Silver “Corner”, 1980 & 0.4 & 2.1 & 0.1 & 1.0 & -0.1 & 0.6 & 0.6 & -0.4 & -0.2 & 0.4 & 0.6 & -0.8 & 1.3 & 0.3 & -0.4 & 0.3 & -0.5 & 0.9 & -0.7 & 0.6 & -0.7 \\
\hline Mean & 0.2 & 0.6 & -0.1 & -0.1 & 0.0 & 0.3 & 0.2 & -0.1 & 0.2 & 0.0 & -1.2 & -0.5 & -0.5 & -0.9 & 0.2 & 0.0 & 0.3 & 0.4 & 0.0 & 0.3 & -0.2 \\
\hline St. Dev. & 0.5 & 1.0 & 0.2 & 0.8 & 1.0 & 0.6 & 0.3 & 0.6 & 2.3 & 0.4 & 2.2 & 0.5 & 2.3 & 2.4 & 1.0 & 1.1 & 1.3 & 0.4 & 0.6 & 0.5 & 0.3 \\
\hline
\end{tabular}


Table 6: Average Daily Volatility for Corner Stocks

We compute the average daily volatility for the pre-corner period, corner period 1 , and corner period 2 . The "open-close" volatility is defined as the volatility of $\ln \left(\right.$ Open $_{t} /$ Close $\left._{t}\right)$. The "close-open" volatility is defined as the volatility of $\ln \left(\right.$ Open $_{t} /$ Close $\left._{t-1}\right)$. In panel B we present t-tests of the null hypothesis of equality of means of groups of successful corners (1) through (6). Opening price quotations are not available for the American Gold Coin corner.

\section{Panel A:}

\begin{tabular}{|c|c|c|c|c|c|c|}
\hline & \multicolumn{2}{|c|}{ Pre-Corner Period } & \multicolumn{2}{|c|}{$\begin{array}{c}\text { Corner Period 1, } \\
{[\mathrm{t}-\mathbf{1 0}, \mathrm{t}]}\end{array}$} & \multicolumn{2}{|c|}{$\begin{array}{c}\text { Corner Period 2, } \\
{[\mathbf{t}+\mathbf{1}, \mathbf{t}+\mathbf{1 0}]}\end{array}$} \\
\hline & $\begin{array}{l}\text { Open-Close } \\
\text { Within-dav }\end{array}$ & $\begin{array}{l}\text { Close-Open } \\
\text { Between-day }\end{array}$ & $\begin{array}{c}\text { Open-Close } \\
\text { Within-day }\end{array}$ & $\begin{array}{l}\text { Close-Open } \\
\text { Between-day }\end{array}$ & $\begin{array}{c}\text { Open-Close } \\
\text { Within-day }\end{array}$ & $\begin{array}{l}\text { Close-Open } \\
\text { Between-day }\end{array}$ \\
\hline & (1) & $(2)$ & (3) & (4) & (5) & (6) \\
\hline \multicolumn{7}{|l|}{ Successful Corners } \\
\hline Harlem, 1863 & 0.043 & 0.032 & 0.025 & 0.018 & 0.034 & 0.018 \\
\hline Harlem, 1864 & 0.037 & 0.036 & 0.016 & 0.019 & 0.005 & 0.006 \\
\hline Prairie du Chien & 0.020 & 0.021 & 0.140 & 0.011 & 0.147 & 0.177 \\
\hline Michigan Southern & 0.012 & 0.010 & 0.019 & 0.016 & 0.039 & 0.030 \\
\hline Erie, $11-1868$ & 0.016 & 0.023 & 0.030 & 0.067 & 0.047 & 0.049 \\
\hline Northwestern & 0.028 & 0.024 & 0.174 & 0.018 & 0.096 & 0.206 \\
\hline Northern Pacific & 0.014 & 0.005 & 0.204 & 0.029 & 0.025 & 0.262 \\
\hline Stutz Motor & 0.032 & 0.020 & 0.048 & 0.021 & - & - \\
\hline Piggly Wiggly & 0.026 & 0.019 & 0.058 & 0.016 & - & - \\
\hline RCA & 0.021 & 0.009 & 0.042 & 0.018 & 0.044 & 0.055 \\
\hline Mean & 0.025 & 0.020 & 0.076 & 0.023 & 0.055 & 0.100 \\
\hline \multicolumn{7}{|l|}{ Failed Corners } \\
\hline Erie, 03-1868 & 0.010 & 0.012 & 0.031 & 0.019 & 0.020 & 0.012 \\
\hline Gold Coin, 1869 & - & - & - & - & - & - \\
\hline Erie, 1872 & 0.019 & 0.018 & 0.018 & 0.010 & 0.031 & 0.011 \\
\hline Silver “Corner”, 1980 & 0.017 & 0.033 & 0.000 & 0.012 & 0.010 & 0.013 \\
\hline Mean & 0.015 & 0.021 & 0.016 & 0.014 & 0.021 & 0.012 \\
\hline
\end{tabular}

Panel B: T-tests of equality of means between groups of successful corners

$\begin{array}{ll}\text { (1) vs. (2) } & 0.29 \\ \text { (1) vs. (3) } & 0.03 \\ \text { (1) vs. (5) } & 0.06 \\ \text { (2) vs. (4) } & 0.57 \\ \text { (2) vs. (6) } & 0.02 \\ \text { (3) vs. (4) } & 0.03 \\ \text { (5) vs. (6) } & 0.25\end{array}$


Table 7: Test of Dynamic Return-Trading Volume Relationship (Llorente et al. (2002))

We present the results of the regression $R_{i, t+1}=C_{0}+C_{1} R_{i, t}+C_{2} R_{i, t} V_{i, t}+C_{3} R_{i, t} V_{i, t} D_{i}+\varepsilon_{i, t+1}$, where $i$ indexes the corresponding cornered security from our sample, $R_{i}$ is the continuously compounded return based on the close price, $V_{i}$ is the natural logarithm of the total number of shares traded, and $D_{i}$ is a dummy variable with value 1 in the $[t-10, t]$ period around the corner date. We also report coefficients from the pooled regression, where we have restricted coefficient $\mathrm{C}_{3}$ to be the same for all stocks/ securities while allowing the other coefficients to vary (fixed effects for $C_{0}, C_{1}$, and $C_{2}$ ), $R_{i, t+1}=\sum_{i=1}^{15} C_{i, 0}+\sum_{i=1}^{15} C_{i, 1} R_{i, t}+\sum_{i=1}^{15} C_{i, 2} R_{i, t} V_{i, t}+C_{3} R_{i, t} V_{i, t} D_{i}+\varepsilon_{i, t+1}$. Single asterisk ( ) indicates $10 \%$ level significance while $\left(^{* *}\right)$ indicates $5 \%$ level significance.

\begin{tabular}{|c|c|c|c|c|c|c|c|c|c|c|}
\hline Company & Obs. & $\mathrm{C}_{0}$ & $\mathrm{C}_{1}$ & $\mathbf{C}_{2}$ & $\mathbf{C}_{3}$ & t-stat $\left(C_{0}\right)$ & t-stat $\left(C_{1}\right)$ & t-stat $\left(C_{2}\right)$ & t-stat $\left(\mathrm{C}_{3}\right)$ & $\mathbf{R}^{2}(\%)$ \\
\hline \multicolumn{11}{|l|}{ Successful Corners } \\
\hline Harlem, 1863 & 75 & 0.00 & -0.28 & 0.02 & 0.04 & 0.05 & -0.19 & 0.11 & 0.90 & 2.0 \\
\hline Harlem, 1864 & 82 & 0.01 & -1.31 & 0.13 & 0.07 & 1.83 & -2.67 & 2.31 & 1.09 & 10.1 \\
\hline Prairie du Chien & 39 & 0.00 & -0.20 & 0.02 & $0.11^{*}$ & -0.08 & -0.23 & 0.13 & 1.79 & 12.6 \\
\hline Michigan Southern & 70 & 0.00 & 1.81 & -0.21 & 0.05 & 0.54 & 0.65 & -0.71 & 1.13 & 4.3 \\
\hline Erie, 11-1868 & 77 & 0.00 & 0.71 & -0.07 & $0.13^{* *}$ & -0.74 & 0.68 & -0.66 & 4.46 & 27.3 \\
\hline Northwestern & 64 & 0.00 & 5.50 & -0.55 & 0.02 & -0.06 & 1.79 & -1.60 & 0.72 & 34.5 \\
\hline Northern Pacific & 66 & 0.02 & 3.25 & -0.46 & $0.19^{* *}$ & 2.92 & 2.94 & -3.88 & 3.00 & 82.4 \\
\hline Stutz Motor & 57 & 0.02 & -1.43 & 0.20 & 0.01 & 2.64 & -1.42 & 1.48 & 0.41 & 13.7 \\
\hline Piggly Wiggly & 68 & 0.01 & 2.37 & -0.32 & 0.02 & 1.78 & 1.69 & -1.84 & 0.53 & 8.3 \\
\hline RCA & 79 & 0.00 & -2.40 & 0.19 & $0.08^{* *}$ & 0.93 & -1.11 & 1.08 & 3.71 & 25.4 \\
\hline $\begin{array}{l}\text { Mean } \\
\text { Pooled Regression } \\
\text { (successful corners) }\end{array}$ & 677 & 0.01 & 0.80 & -0.10 & $\begin{array}{c}0.07 \\
0.04^{* *}\end{array}$ & & & & 4.18 & 37.7 \\
\hline \multicolumn{11}{|l|}{ Failed Corners } \\
\hline Erie, 03-1868 & 74 & 0.00 & 1.61 & -0.15 & 0.00 & -0.35 & 0.63 & -0.58 & 0.12 & 1.9 \\
\hline Gold, 1869 & - & - & - & - & - & - & - & - & - & - \\
\hline Erie, 1872 & 79 & 0.00 & 0.88 & -0.09 & -0.02 & -0.17 & 0.46 & -0.52 & -0.47 & 2.1 \\
\hline Silver “Corner”, 1980 & 132 & 0.00 & 1.97 & -0.20 & 0.08 & -0.42 & 1.42 & -1.36 & 0.83 & 2.8 \\
\hline $\begin{array}{l}\text { Mean } \\
\text { Pooled Regression } \\
\text { (failed corners) }\end{array}$ & 285 & 0.00 & 1.49 & -0.15 & 0.02 & & & & 0.60 & 2.2 \\
\hline Overall Pooled Regression & 962 & & & & $0.04^{* *}$ & & & & 4.11 & 29.4 \\
\hline
\end{tabular}


Figure 1. Cumulative Abnormal Trading Volume (Standardized)

Abnormal trading volume is defined as the difference between daily volume in the corner period and the pre-corner period average daily trading volume. We standardize this variable with the standard deviation of the pre-corner period daily volume. In the figure, we have accumulated the trading volume across the corner period, i.e. at date t-10 we have plotted the abnormal trading volume at that day, at date $\mathrm{t}-9$ we have plotted the sum of the variable values at dates t10 and $\mathrm{t}-9$, etc.

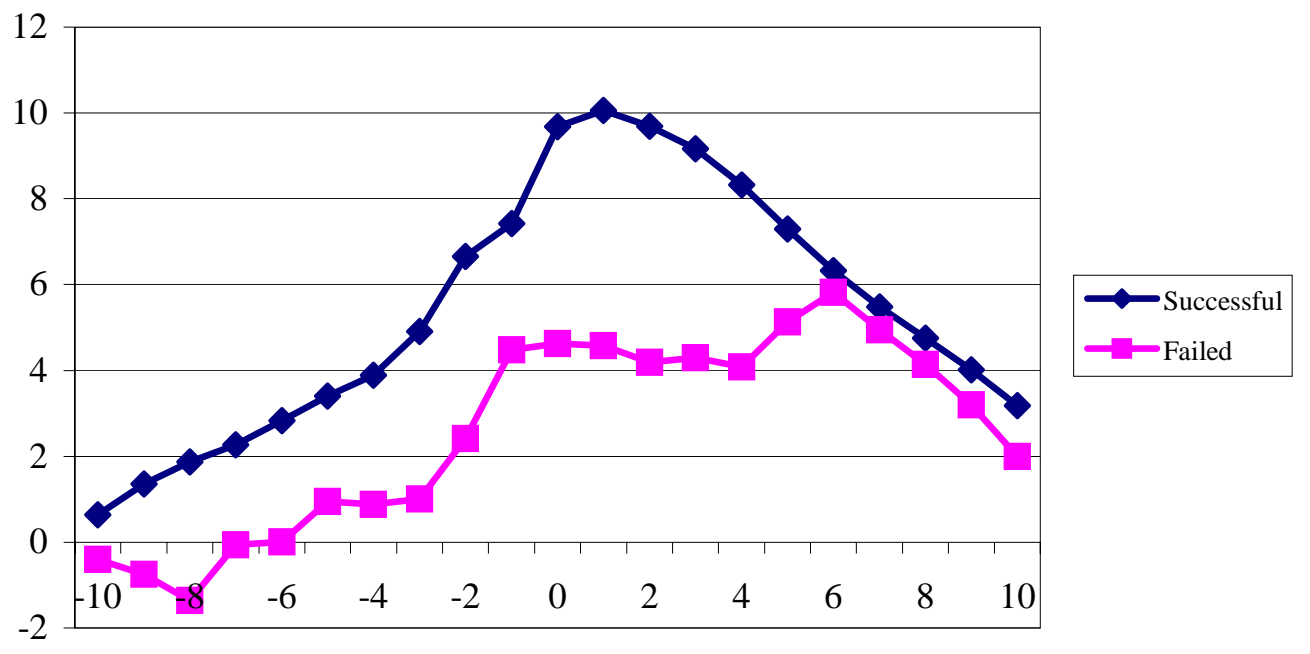

Corner Date

Figure 2. Cumulative Abnormal Returns (Standardized)

Abnormal standardized returns are defined as the daily return in the corner period in excess of the average daily return in the pre-corner period, standardized by the standard deviation of the pre-corner daily return. Thus the vertical axis is to be read as standard deviation units around the pre-corner mean. In the figure, we have accumulated the standardized abnormal return over the course of the corner period, i.e. at date $t-10$ we have plotted the abnormal standardized daily return at that day, at date $\mathrm{t}-9$ we have plotted the sum of the variable values at dates $\mathrm{t}-10$ and $\mathrm{t}-9$, etc.

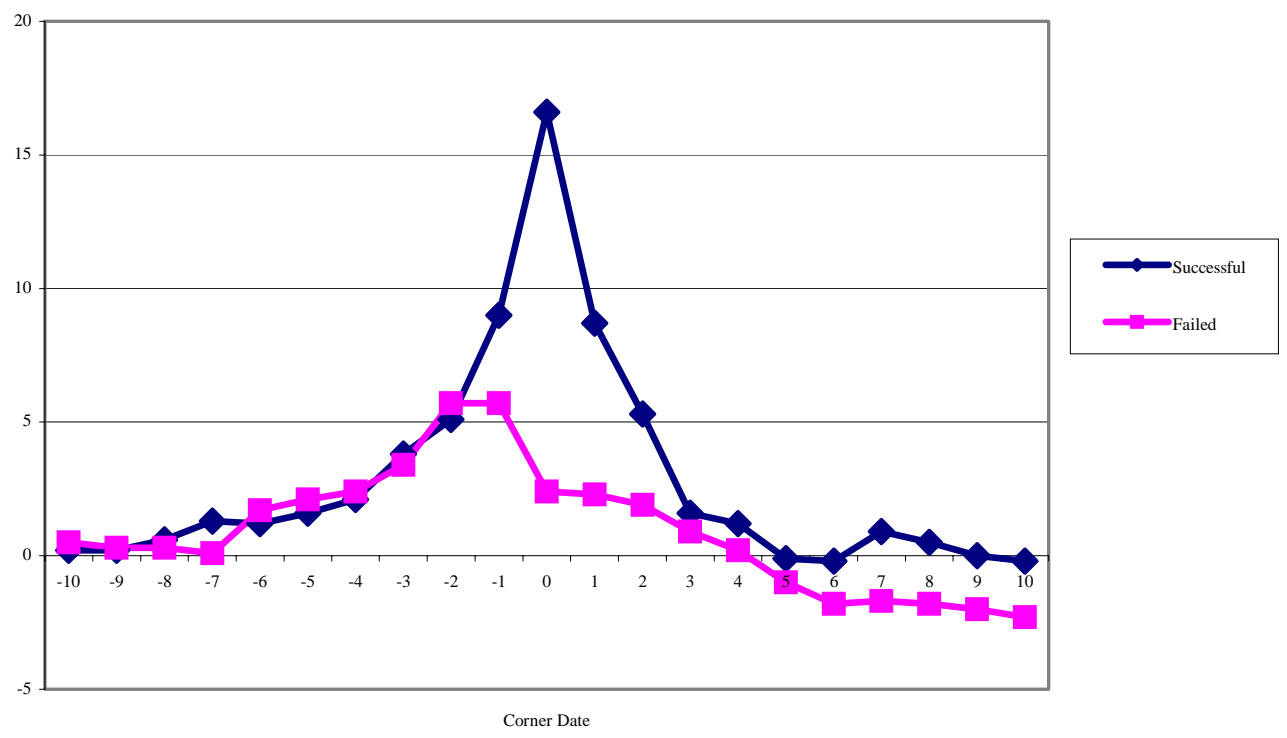


Figure 3. Daily Price Dispersion (High-Low) as a Percentage of Closing Prices

Daily price dispersion is the difference between the high and low prices within a given trading day as a percentage of the close price.

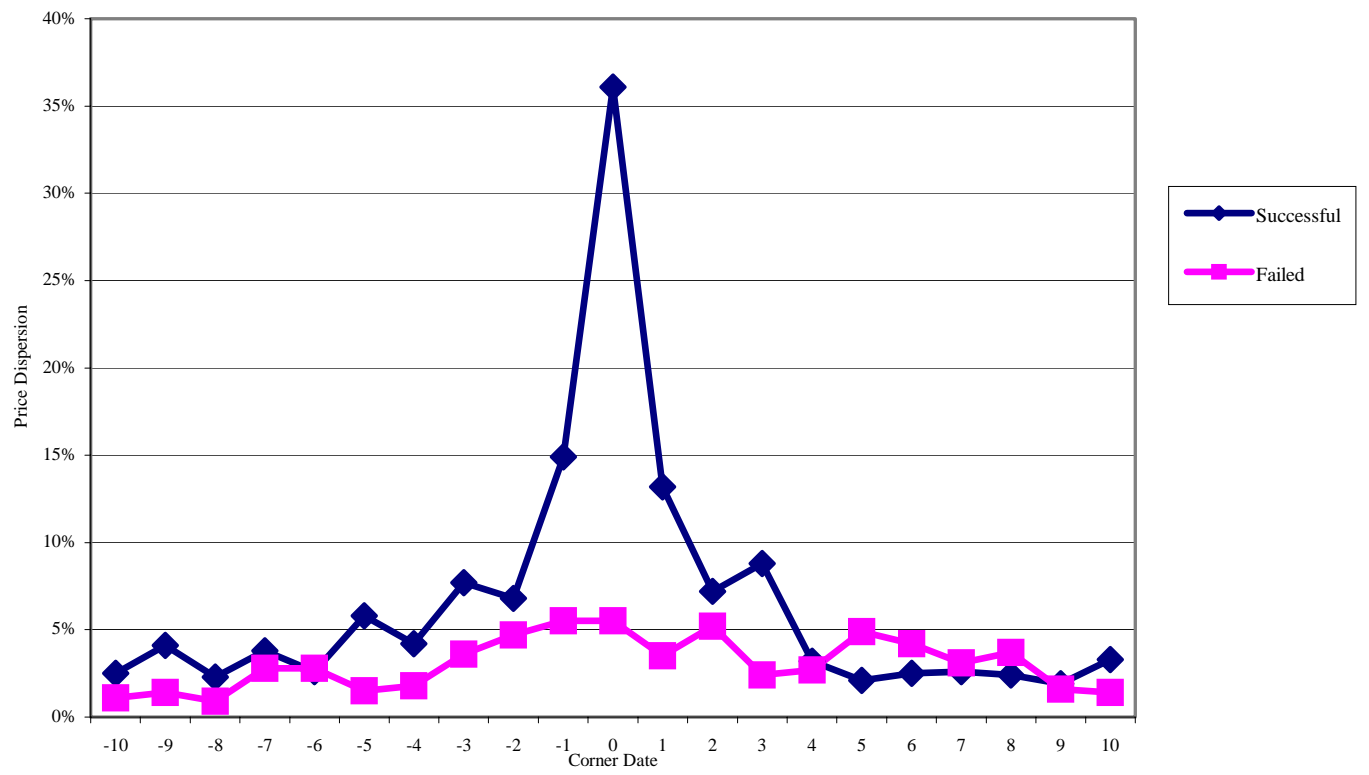

Figure 4. Cumulative Excess Returns (5 corners only)

We exhibit the cumulative excess return for five corners: Northern Pacific, Stutz Motor, Piggly Wiggly, RCA, and the Silver futures. Our sample is limited to these stocks since market return data is available only for them for the whole sample period. Of these the only failed corner is the one for silver futures. Excess return is defined as the residual of the regression: $R_{i, t}=\alpha+\beta R_{m, t}+\varepsilon_{t}$, estimated for the pre-corner period, where $R_{i}$ is the company i return, and $R_{m}$ is the market return. For Northern Pacific we use as market return the daily return for Dow Jones Transports/Rails index. For Stutz Motor, Piggly Wiggly, RCA, and the silver futures on COMEX, we have used as daily market return on the Dow Jones Industrial Average index.

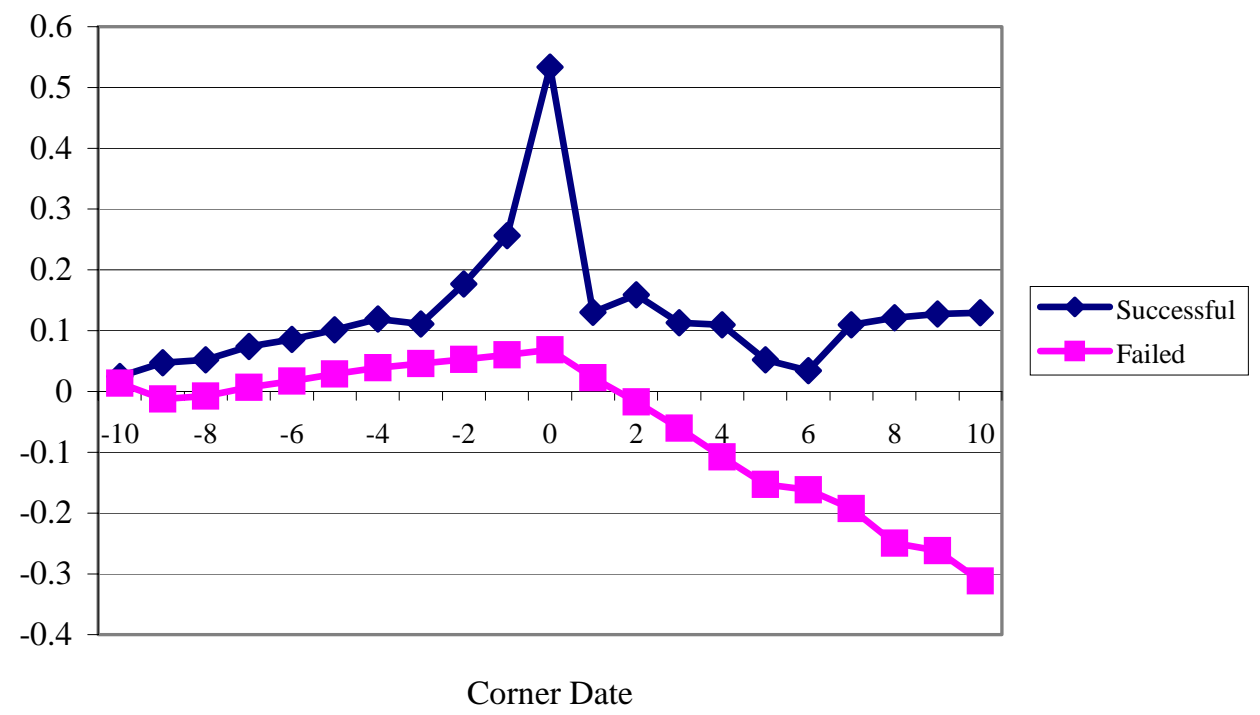


Figure 5. Cumulative Market Return around Corner Date (5 corners only)

We exhibit the cumulative market return for five corners: Northern Pacific, Stutz Motor, Piggly Wiggly, RCA, and the Silver futures. In the figure, we have accumulated the market return across the corner period, i.e. at date $t-10$ we have plotted the market return at that day, at date $\mathrm{t}-9$ we have plotted the sum of the market returns at dates $\mathrm{t}-10$ and $\mathrm{t}-9$, etc.

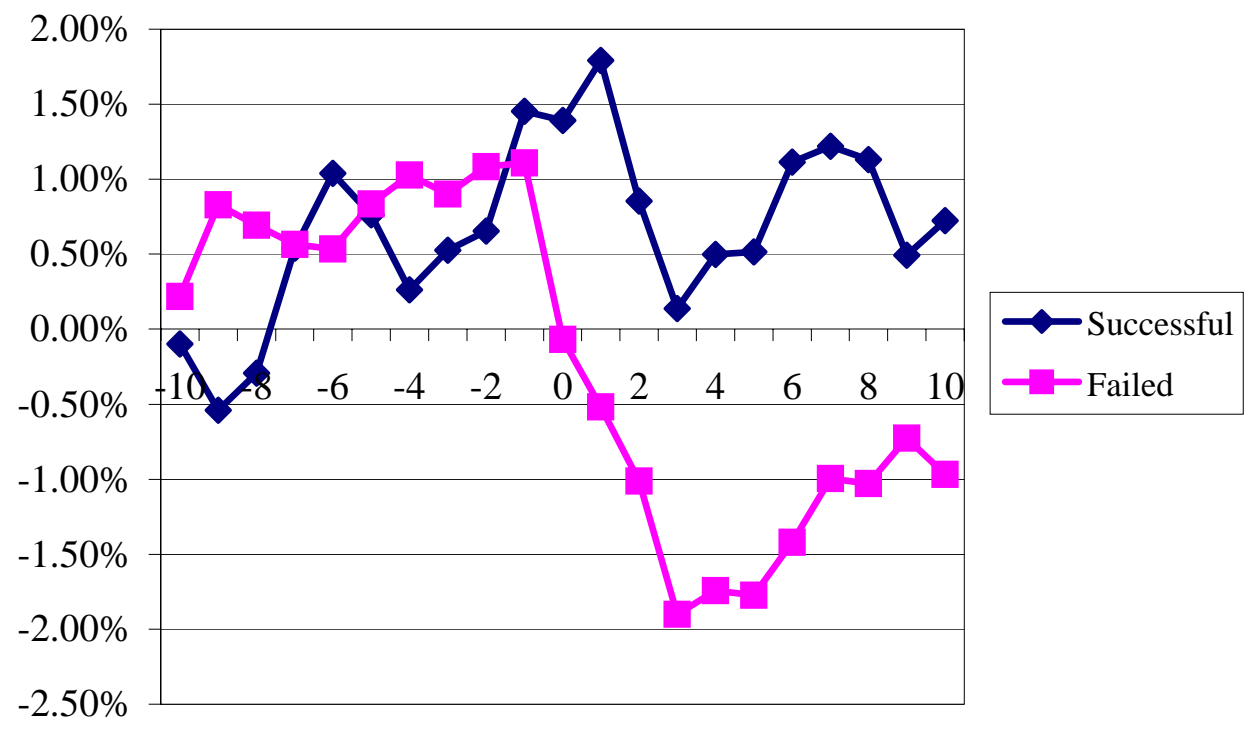

Corner Date 


\section{Appendix A: Famous Market Corners In America's Financial History}

\section{The First Harlem Corner ${ }^{16}$ (1863)}

Allen and Gale (1992) describe the 1863 Harlem corner: “At the beginning of 1863, Commodore Cornelius Vanderbuilt bought stock in the Harlem Railway at around \$8 to \$9 a share. He took an interest in running the company and its stock price advanced to \$50 per share. In April, 1863, the New York City Council passed an ordinance allowing the Harlem Railway to build a streetcar system the length of Broadway and, as a result, the stock price went to $\$ 75$. Members of the council (and Daniel Drew, a director of the company) then conspired to sell the stock short, repeal the ordinance, and thus force the price down. However, Vanderbuilt discovered the plot and managed to buy the entire stock of the company in secret. When the members of the council tried to cover their short positions after the repeal of the ordinance, they discovered that none of the stock could be purchased. Vanderbuilt forced them to settle at \$179 per share.”

\section{The Second Harlem Corner ${ }^{17}$ (1864)}

After the betrayal by the New York City Council, Vanderbilt decided to go to Albany to get his Harlem Railway extension directly from the New York State Legislature. Hoping for revenge, Drew conspired with the unwary state legislators to spread news about the likely passing of the legislation, push up the price, then proceed to sell the stock short, defeat the bill, and force the price down. The stock price dropped from \$150 to \$100 in two days. Vanderbilt was furious and bought more shares than were actually in existence. He forced the short sellers to settle at \$285 and Drew again lost over half a million dollars.

\section{The Prairie du Chien Corner ${ }^{18}$ (1865)}

On Nov. $6^{\text {th }}$, 1865, a bull pool led by William Marston, a well known stock market operator at the time was reported by the New York Times as having gained control of the entire outstanding 29,880 shares of Prairie du Chien Railroad Company as well as a similar amount of short interests. The pool called for a settlement that morning, which led to “...one of the sharpest and beyond all precedent the most sudden corner known to the forty years’ history of the New-York Stock Exchange.”

\footnotetext{
${ }^{16}$ Chancellor (2000), chapter 6 and Allen and Gale (1992).

${ }^{17}$ Clews (1888), chapter 34.

${ }^{18}$ See New York Times, 11/07/1865, Financial Affairs section.
} 


\section{The Michigan Southern Corner $^{19}$ (1866)}

No details were found.

\section{The Failed Erie Corner $^{20}$ (March 1868)}

In 1868, Vanderbilt set out to wrestle control of the Erie Railroad from Daniel Drew and Jay Gould. He was confident due to his victories in the Harlem battles and he had as his allies a group of Boston capitalists who had a large block of Erie stocks. So he proceeded to buy control of the company while Drew and Gould were selling. He poured millions into the purchase of the stock and had apparently bought more stocks than were in existence. So it looked as if the short sellers were cornered. However, Drew was well prepared this time. As a director of the company, he surprised Vanderbilt by converting a large hidden issue of convertible bonds into common stocks and flooded the market with these new shares. Vanderbilt's corner was broken after he had sunk in seven million dollars for Erie stock.

\section{The Erie Corner $^{21}$ (November 1868)}

In late 1868, Drew and Gould were involved in a bear raid on the market by selling Erie and other stocks short. Then they tried to force the interest rates up and a general market decline by a large withdrawal of funds from New York banks. Agitated by Drew's wavering during the operation, Gould suddenly switched his strategy from bear raid to bull run. Unaware of Gould's switch, Drew kept on selling Erie short. The price dropped from \$50 to \$40 in October and went further down to \$35 on November 13. But Gould by then had bought all the floating shares of Erie. On November 16, the price suddenly jumped to \$55 and Drew was cornered with 70,000 shares short.

\footnotetext{
${ }^{19}$ Chancellor (2000), chapter 6.

${ }^{20}$ Chancellor (2000), chapter 6.

${ }^{21}$ Sharp, R. (1989).
} 


\section{The Failed Gold Coin Corner $^{22}$ (1869)}

In 1868, the whole floating supply of gold was about \$20 million and the government held about \$75 million in reserve. Jay Gould thought that this whole supply could be cornered and thus selling it at an inflated price. He conspired with Abel Corbin, the brother-in-law of President Grant, to influence government policy on gold. On numerous occasions, he lobbied Grant and government officials on the benefits of high gold prices. For a moment, it appeared that Grant was quite convinced. Gould proceeded to accumulate a $\$ 50$ million position in gold and the price had risen from 130 to 137 . To increase his chance of success, Gould then launched an aggressive lobbying of government officials who began to suspect his speculative motives. Sensing the government might intervene to break his corner, he secretly sold his position while urging his friends to buy at any price. On October 4, the feverish purchase by Gould's friends had pushed the gold price from 140 to 160, but government selling later during the day quickly broke the squeeze and brought the price back to $\$ 140$. This day had gone down in history as another Black Friday, since hundreds of firms on Wall Street were ruined by the huge price swing.

\section{The Failed Erie Corner ${ }^{23}$ (1872)}

In the summer of 1872, Jay Gould asked Daniel Drew and Henry Smith to join him for a bear raid on Erie stocks. They conspired to depress the stocks by suddenly withdrawing large sums of money from New York banks, which created a small liquidity crisis due to the lack of lenders of last resort at the time. But Drew turned bullish after their initial success. So he reversed his trades and proceeded to build a large position without notifying Gould and Smith. On September 17, he cornered the market by calling for a settlement. But Gould was able to deliver the stocks. However, the corner had a large impact on the prices of all stocks.

\section{The Northwestern Corner $^{24}$ (1872)}

In November 1872, Jay Gould tricked Daniel Drew and Henry Smith into joining him for another bear raid by selling Northwestern stock short. Not suspecting Gould's intention, they kept selling the stock short while Gould at the same time was building a huge position. The rising price made Smith suspicious and he got a warrant for Gould's arrest on charges of looting the Erie treasury. Gould wriggled out of the charges and decided to ruin Drew and Smith by cornering the market on Northwestern. The

\footnotetext{
${ }^{22}$ Chancellor (2000), chapter 6.

${ }^{23}$ Chancellor (2000), chapter 6 .

${ }^{24}$ Chancellor (2000), chapter 6.
} 
price soared from $\$ 80$ to $\$ 230$ in a few days and they were asked to settle at that price. The corner had a serious impact on the prices of all stocks. ${ }^{25}$

\section{The Northern Pacific Corner ${ }^{26}$ (1901)}

In spring 1901, J.P. Morgan and a group of investors led by Edward Harriman fought for the control of Northern Pacific Railroad, which could lead to gaining control of railroad traffic to the Pacific coast. Harriman started by acquiring $\$ 40$ million from the common stock, running just short of 40,000 shares of gaining control. Alarmed by the scheme, J.P. Morgan went out to acquire the rest of stocks and his purchase sent prices soaring from $\$ 114$ to $\$ 147$ in 5 days. Noticing the unusual increase in the price, a group of short sellers built a large short interest volume in the stock. On May $9^{\text {th }}$ short sellers realized that they were caught in an unintended corner, and the price went from \$170 to a record level of \$1000 during the day. The market for other stocks plummeted since short sellers were pressed to cover their positions by selling their other assets. ${ }^{27}$ The volume traded was 3,336,000 for the day, a record not broken until 1925. Morgan and Harriman agreed to settle with the short sellers at $\$ 150$ the next day.

\section{The Stutz Motor Company of America, Inc. $\operatorname{Corner}^{28}$ (1920)}

Allan Ryan, known in the early twentieth century as a speculator good at the art of squeezing short sellers, had bought a controlling interest in the Stutz Motor Company of America, Inc. At the beginning of 1920 , its price had risen steadily from $\$ 100$ to $\$ 134$. Ryan was told that short sellers had taken action thinking that the price had risen too high. Among this bear raid were some prominent members of the stock exchange. To counter the bears, Ryan borrowed substantial amounts to buy additional shares. At first, despite Ryan's heavy purchase, the price went down, since the short-selling pressure was considerable. But then the price shot up late March, reaching \$391. Towards the end of March, the stock the short sellers were selling had to be borrowed from Ryan, since he had almost all floating shares. On March $31^{\text {st }}$, the Governing Committee of NYSE announced that it had decided to suspend all dealings in Stutz Motor stock for an indefinite period due to irregular price gyrations. On April $20^{\text {th }}$, the Protective committee of NYSE announced that it was ready to accept impartial mediation on a negotiated-settlement price that led to a settlement at the price of $\$ 550$. Shortly after this fiasco, the NYSE quietly amended its

\footnotetext{
${ }^{25}$ See New York Times, November $26^{\text {th }}, 1872$ and also Chancellor (2000), page 171.

${ }^{26}$ Thomas (1989).

${ }^{27}$ Kyle and Xiong (2001) develop a model that captures the contagion effect.

${ }^{28}$ Brooks (1969).
} 
constitution by allowing the governing committee to postpone the time for deliveries on contracts for the purpose of preventing market corners.

\section{The Piggly-Wiggly Corner $^{29}$ (1923)}

Piggly-Wiggly was a grocery chain in the Midwest. Clarence Saunders, the president of PigglyWiggly, wished to make a seasoned equity offering. To raise the price of the stock, he hired a well known stock manipulator, Jesse Livermore, to push up the stock price. The rising price attracted substantial short interest, which eventually led to a market squeeze in mid-March. Given his large position, Clarence Saunders thought that he could make more money by canceling his previous plan to issue more stocks and thus make the bears pay even more. On March 23, price soared 50 points in a single day. However, the governors of the Big Board decided to delist Piggly-Wiggly the next day, and let the bears buy the stock at a nominal price.

\section{The Radio Corporation of America Corner ${ }^{30}$ (1928)}

In 1927, William Durant, an automobile legend turned speculator, took an interest in a young company, Radio Corporation of America. He noted that the bulk of the shares issued by RCA were held by RCA itself, General Electric, Westinghouse, and several other big corporations, and these shares were not traded. In addition, there was much hype on the market for RCA, since its radio transmission was considered a revolution in communications technology at the time. Thus Durant started a pool to accumulate the RCA stock. As a result of the feverish purchases by the Durant group, they soon bought almost all floating shares as well as shares sold short. Their trading generated daily turnover of above 500,000 shares, while officially there were only 400,000 floating available. The pool forced the market into a technical corner in March 1928. The corner was unintentional because a large part of the shares was not under the control of the manipulators and they never call for a settlement. From March $12^{\text {th }}$, the bears started struggling to settle their accounts and the price rose more than $\$ 61$ in four days.

\footnotetext{
${ }^{29}$ Brooks (1969).

30 Thomas (1989).
} 


\section{The Silver Corner $^{31}$ (1980)}

In 1974, Bunker and Herbert Hunt, children of the Texas oil magnate H.L. Hunt, started investing in silver as a hedge against inflation. As they controlled more and more of the world's silver, the price shot up from \$11 an ounce to more than \$50. To alleviate speculation on the New York Metals Market, The New York Commodities Exchange (COMEX) changed its trading rule by placing a 500 contract limit that traders may hold. Afterwards, as silver prices slid, the Hunt brothers failed to meet huge margin call on their futures contracts, sparking a panic on commodity and futures exchanges and a 50\% plunge of prices from \$21.62 to \$10.80 on March 27, 1980. Later, former Federal Reserve Board chairman Paul Volcker estimated that 'at one point' during this winter Hunt-related interests may have controlled twothirds of the 170 million ounces of US silver stocks. He also reported to Congress that the Hunt brothers were seeking more than \$1 billion to help them restructure their silver trading debts in April 1980.

\footnotetext{
${ }^{31}$ Dow Jones New Service, 4/30/1980, “Volcker Says Hunts Seeking Over \$1 Billion For Silver Debts” and “Volcker Discloses Hunt Silver Debts”.
} 


\section{Appendix B: Price and Volume Chart of Well Known Market Corners}

Figure 1A.

Company: Harlem, Corner Date: 08/24/1863

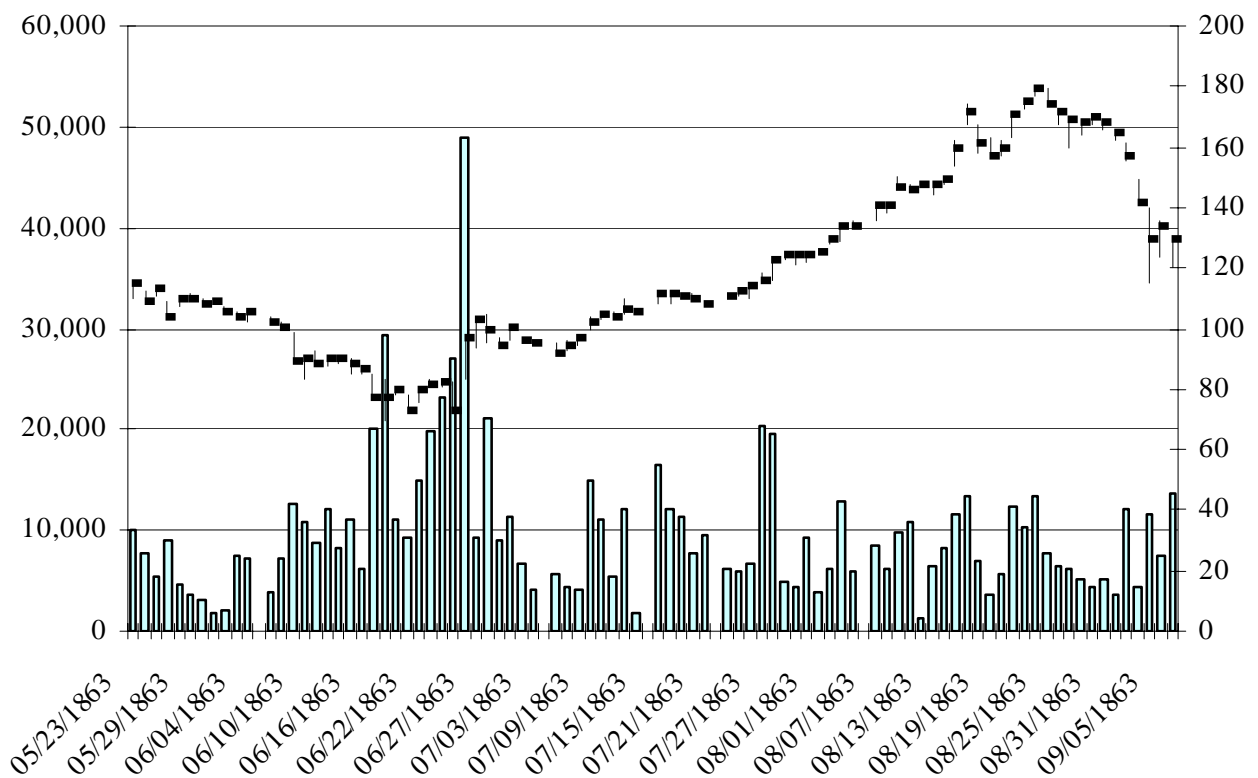

$\square$ Volume
High
Low
- Close

Figure 2A.

Company: Harlem, Corner Date: 05/17/1864

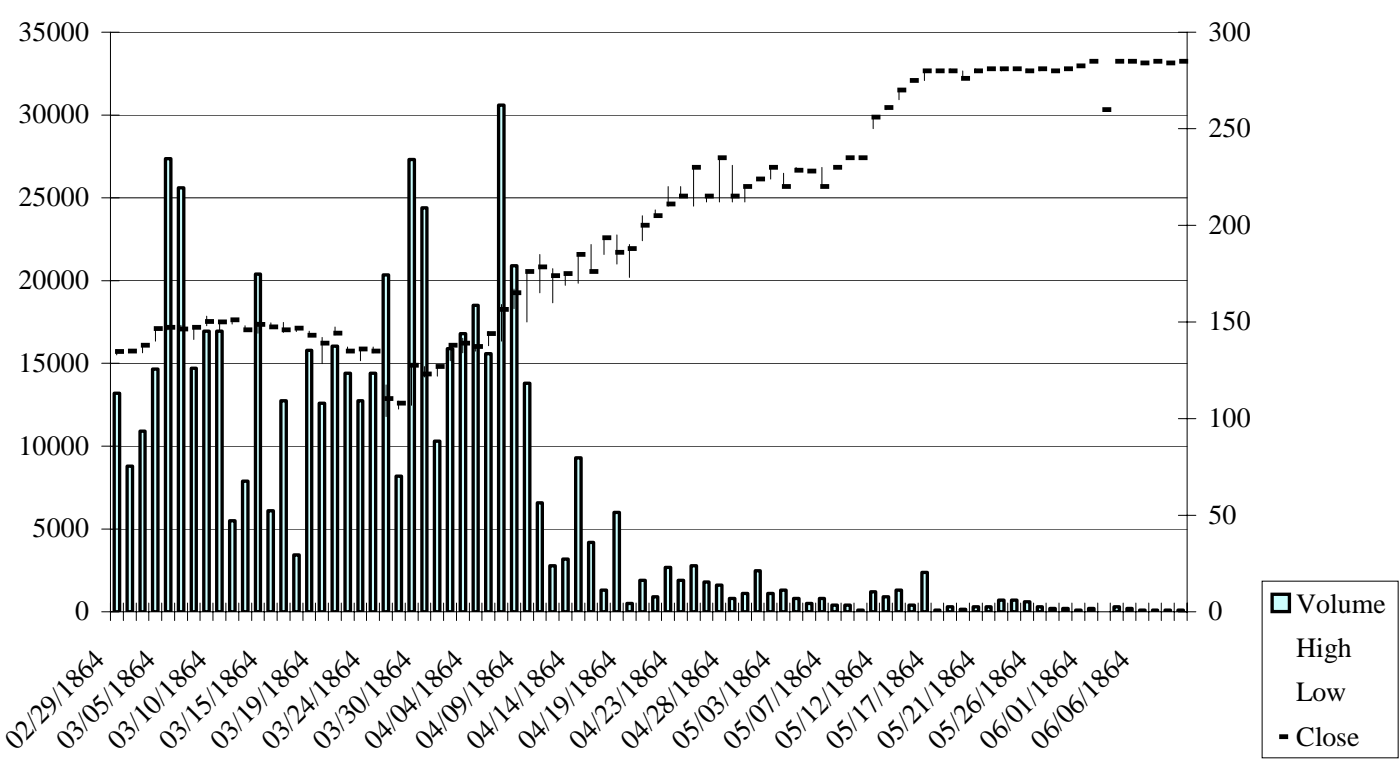




\section{Figure 3A.}

Company: Prairie du Chien, Corner Date: 11/06/1865

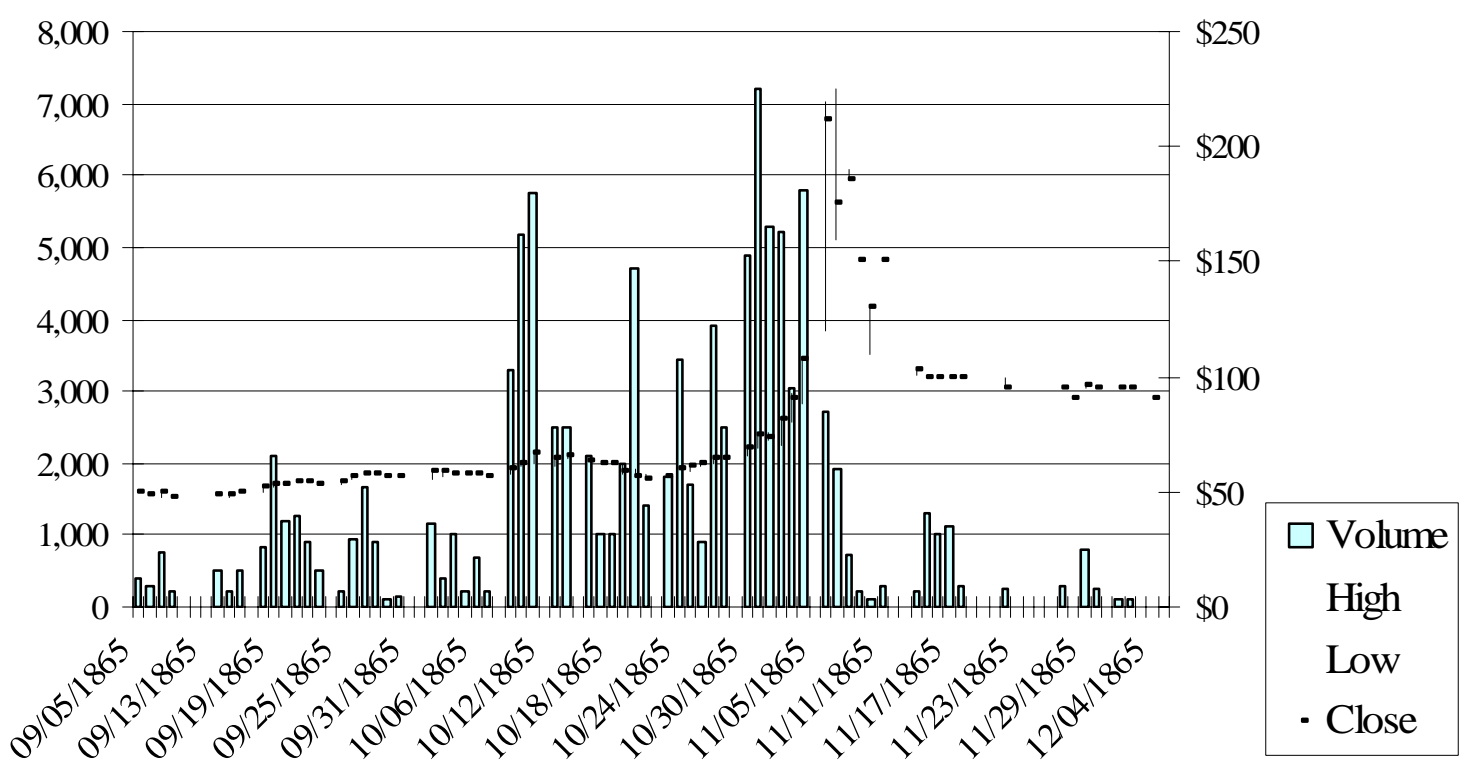

Figure 4A.

Company: Michigan Southern, Corner Date: 04/04/1866

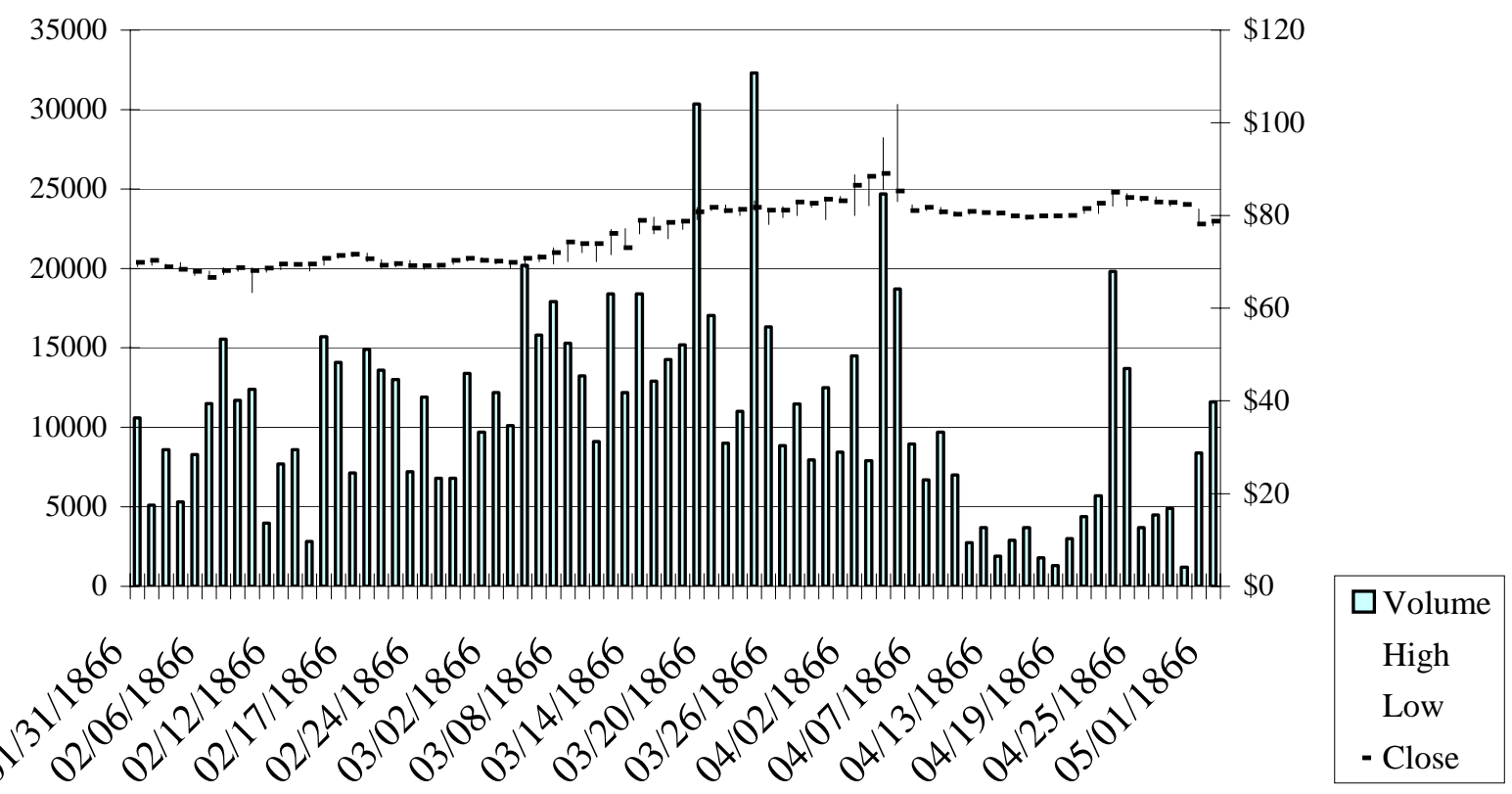




\section{Figure 5A.}

Company: Erie Railroads, Corner Date: 3/10/1868
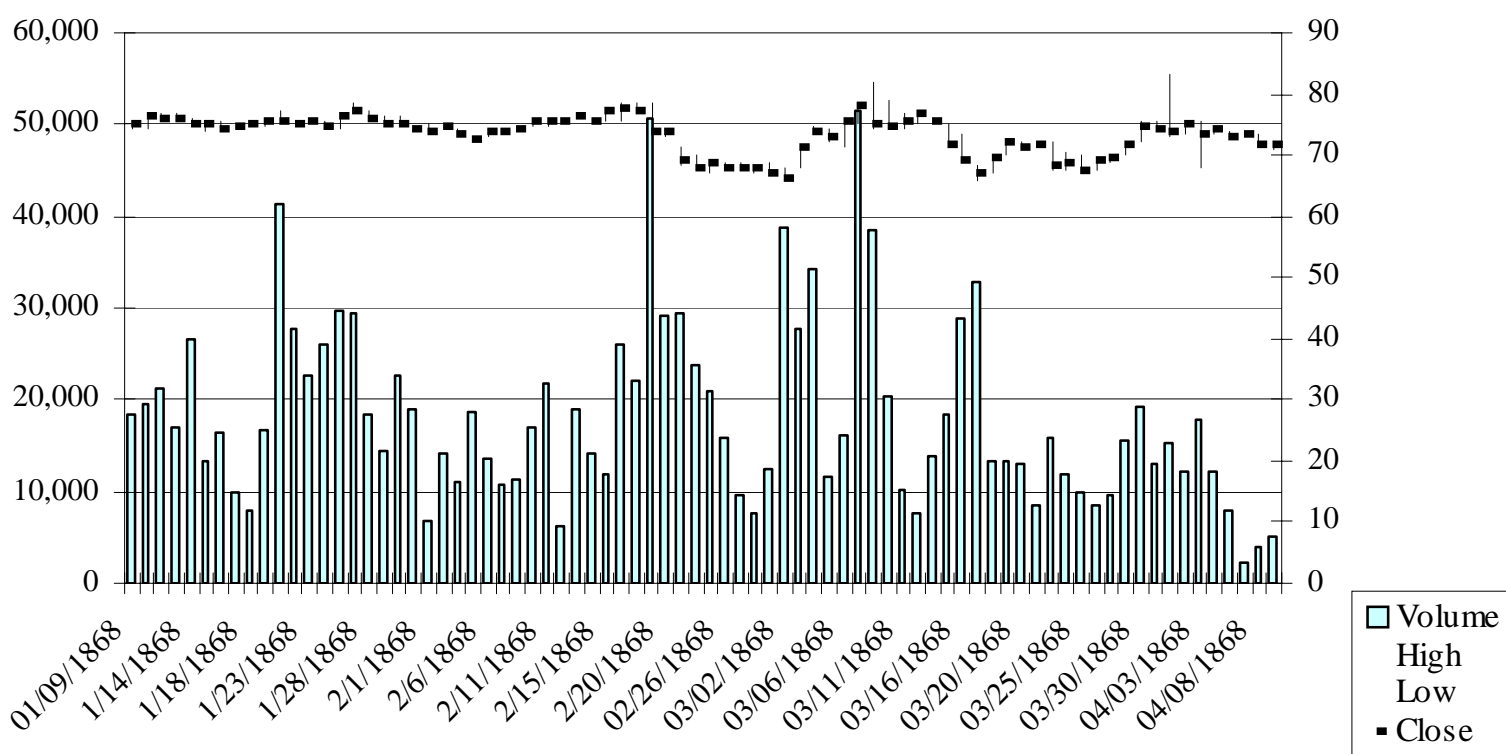

Figure 6A.

Company: Erie Railroads, Corner Date: 11/16/1868

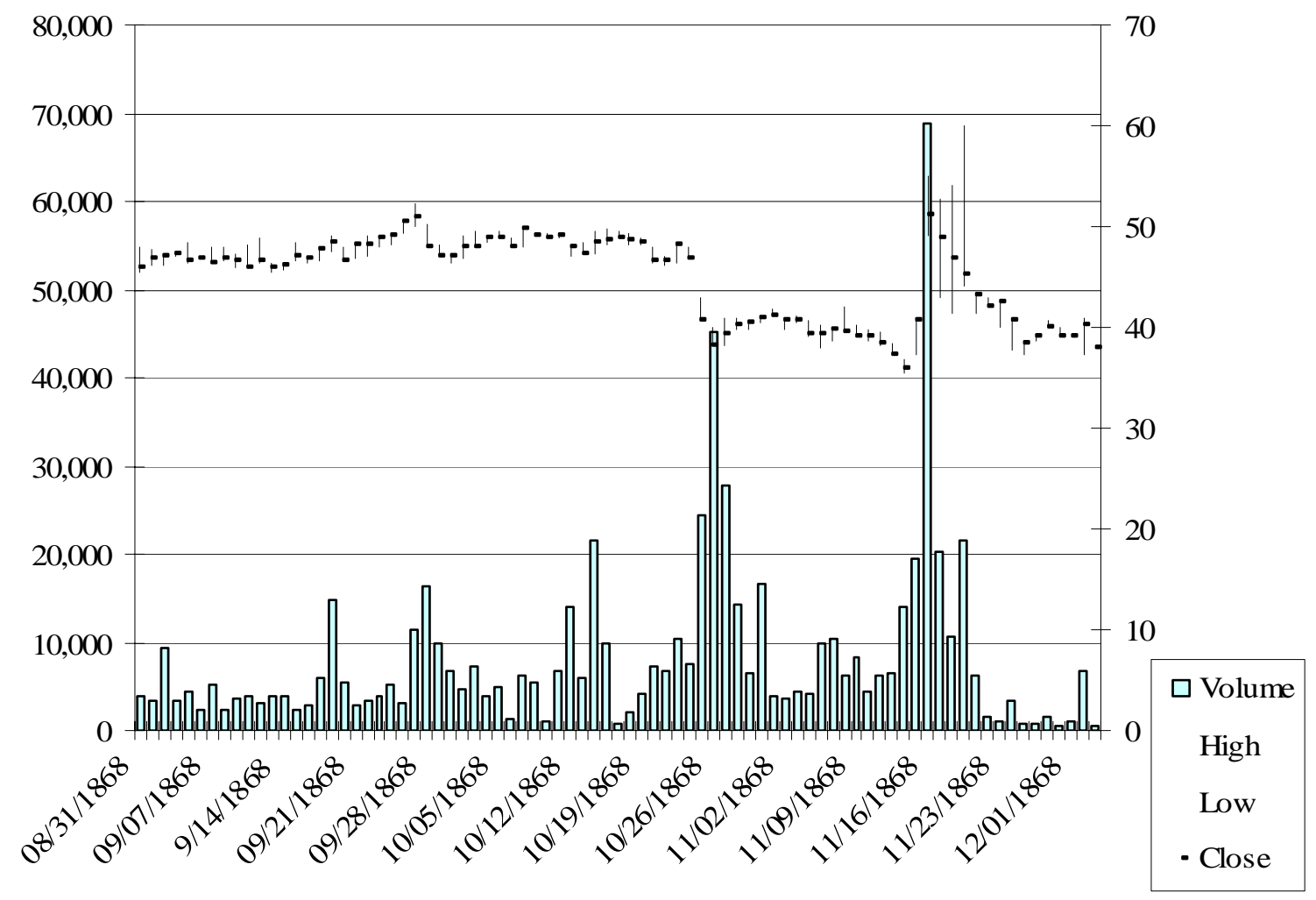




\section{Figure 7A.}

American Gold Coin, Corner Date: 09/24/1869
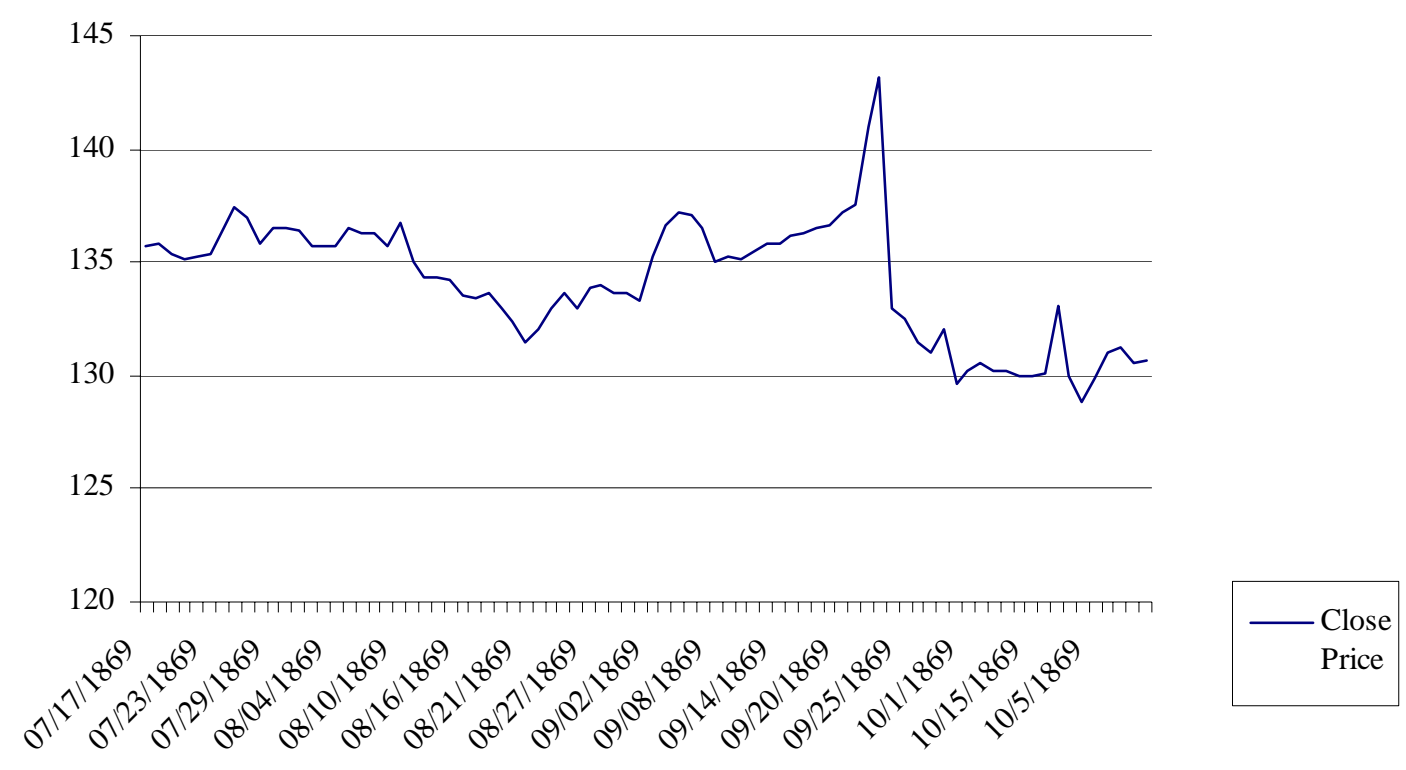

Figure 8A.

Company: Northwestern, Corner Date: 11/23/1872

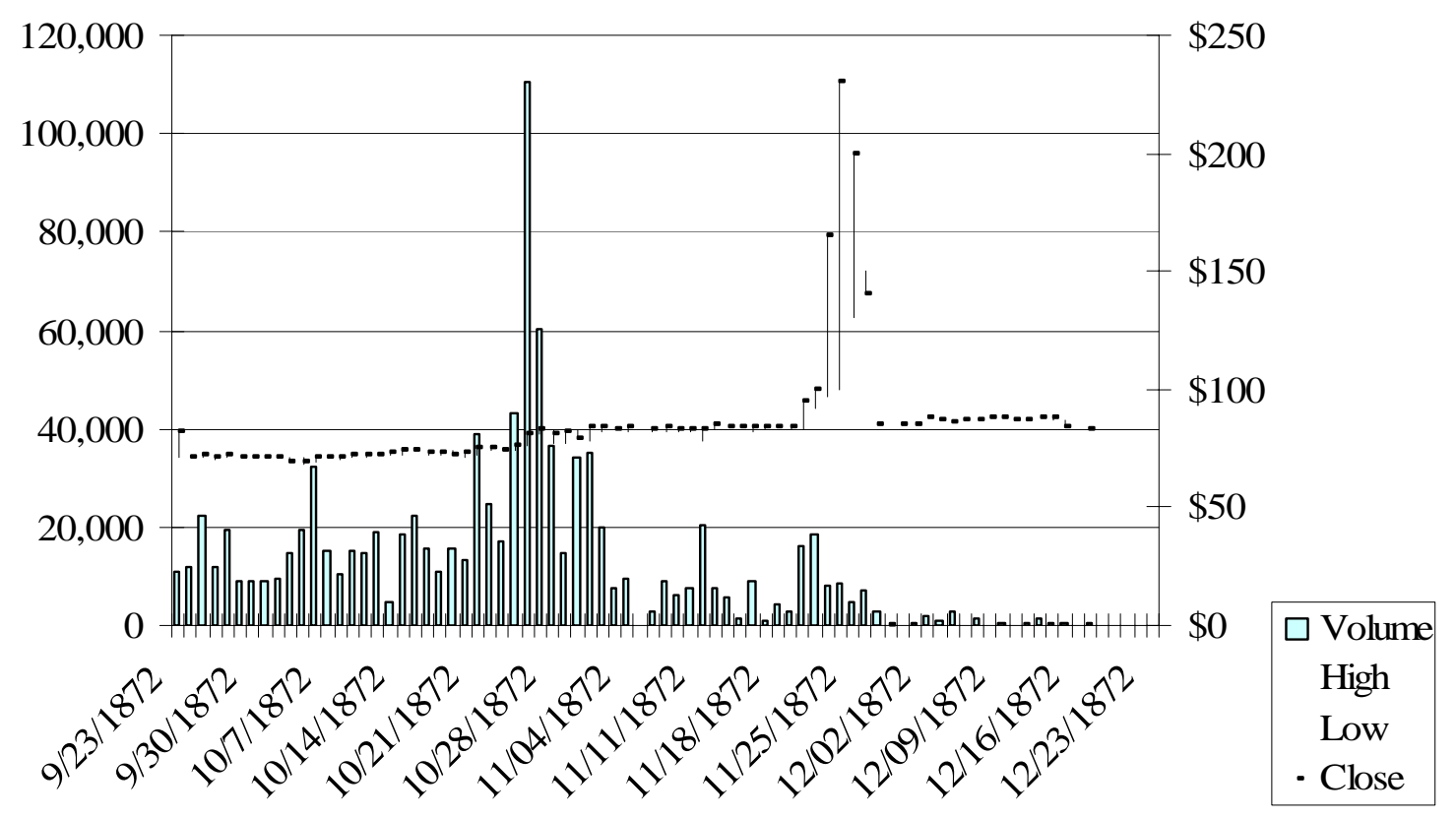




\section{Figure 9A.}

Company: Erie Railroad, Corner Date: 09/17/1872

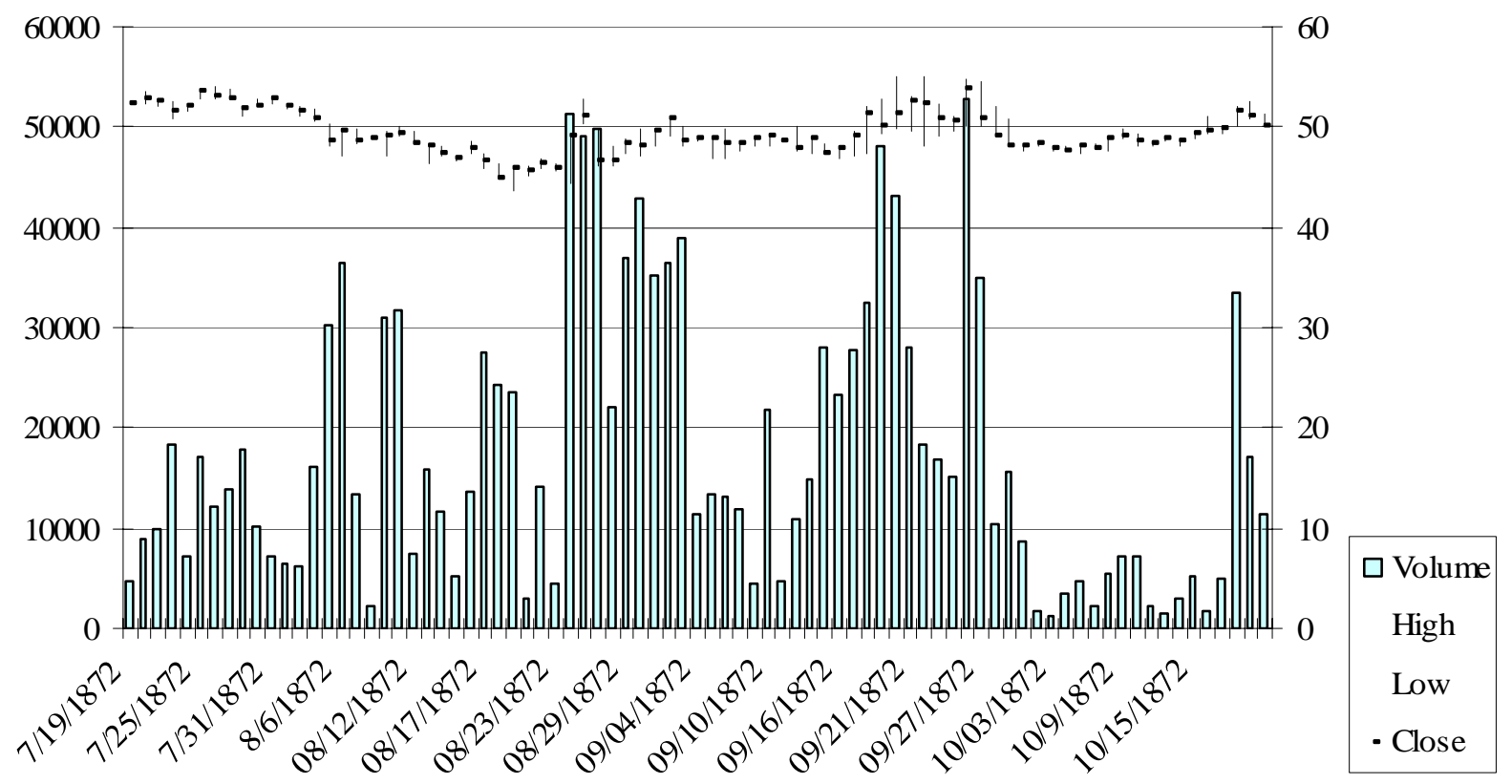

Figure 10A.

Company: Northern Pacific, Corner Date: 05/09/1901

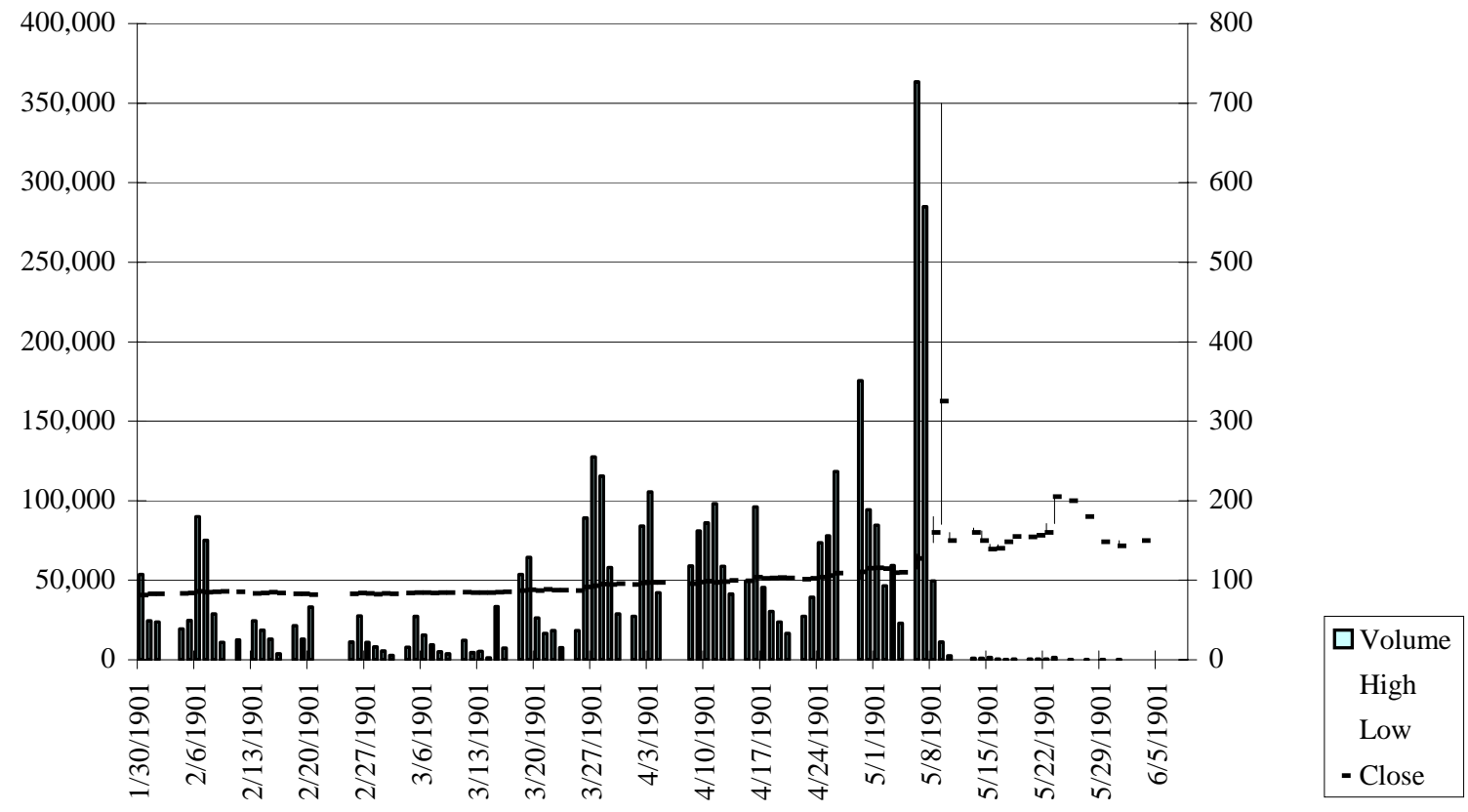


Figure 11A.

Company: Stutz Motor, Corner Date: 04/26/1920

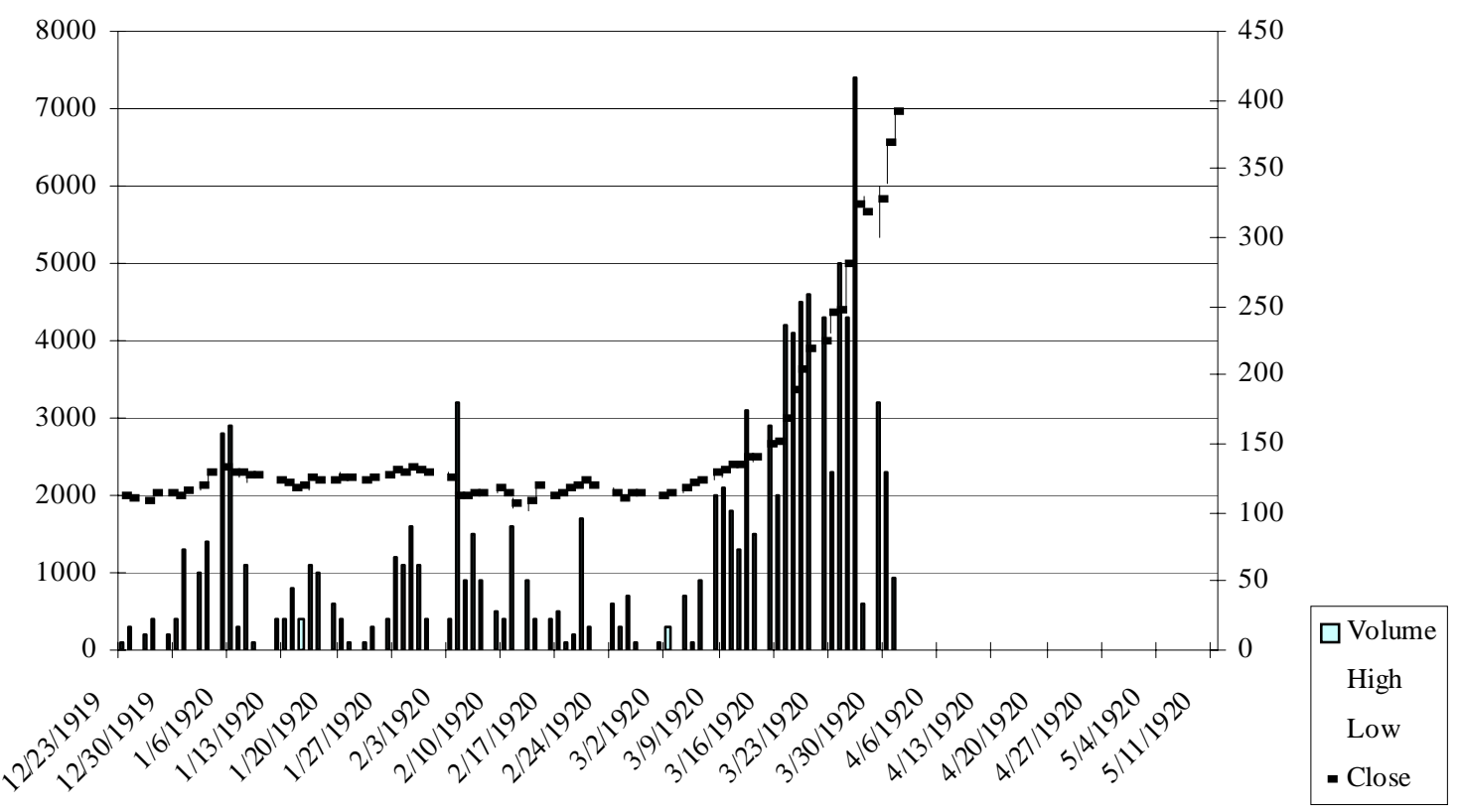

Figure 12A.

Company: Piggly Wiggly, Corner Date: 03/20/1923

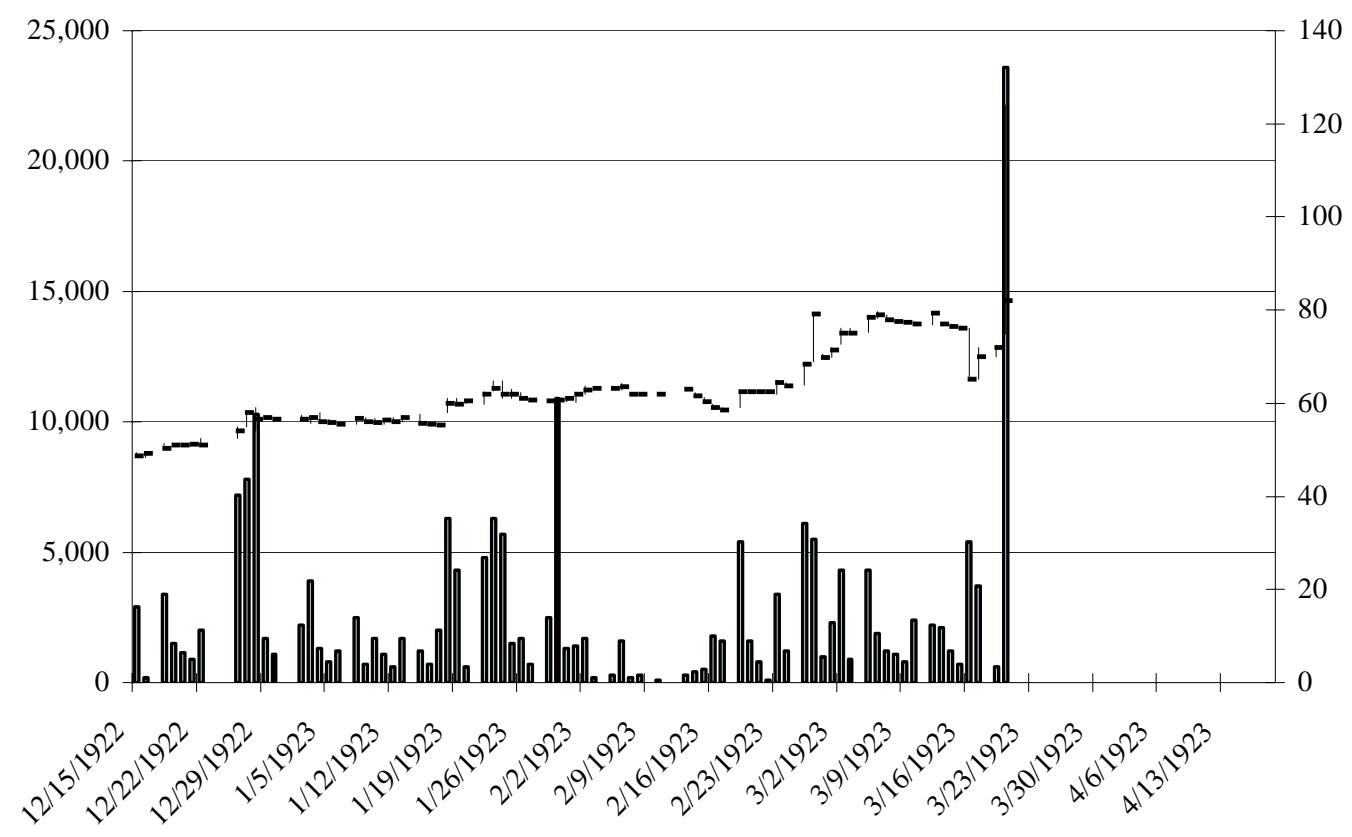

\begin{tabular}{|c|}
\hline$\square$ Volume \\
High \\
Low \\
- Close
\end{tabular} 
Figure 13A.

Company: RCA, Corner Date: 3/12/1928

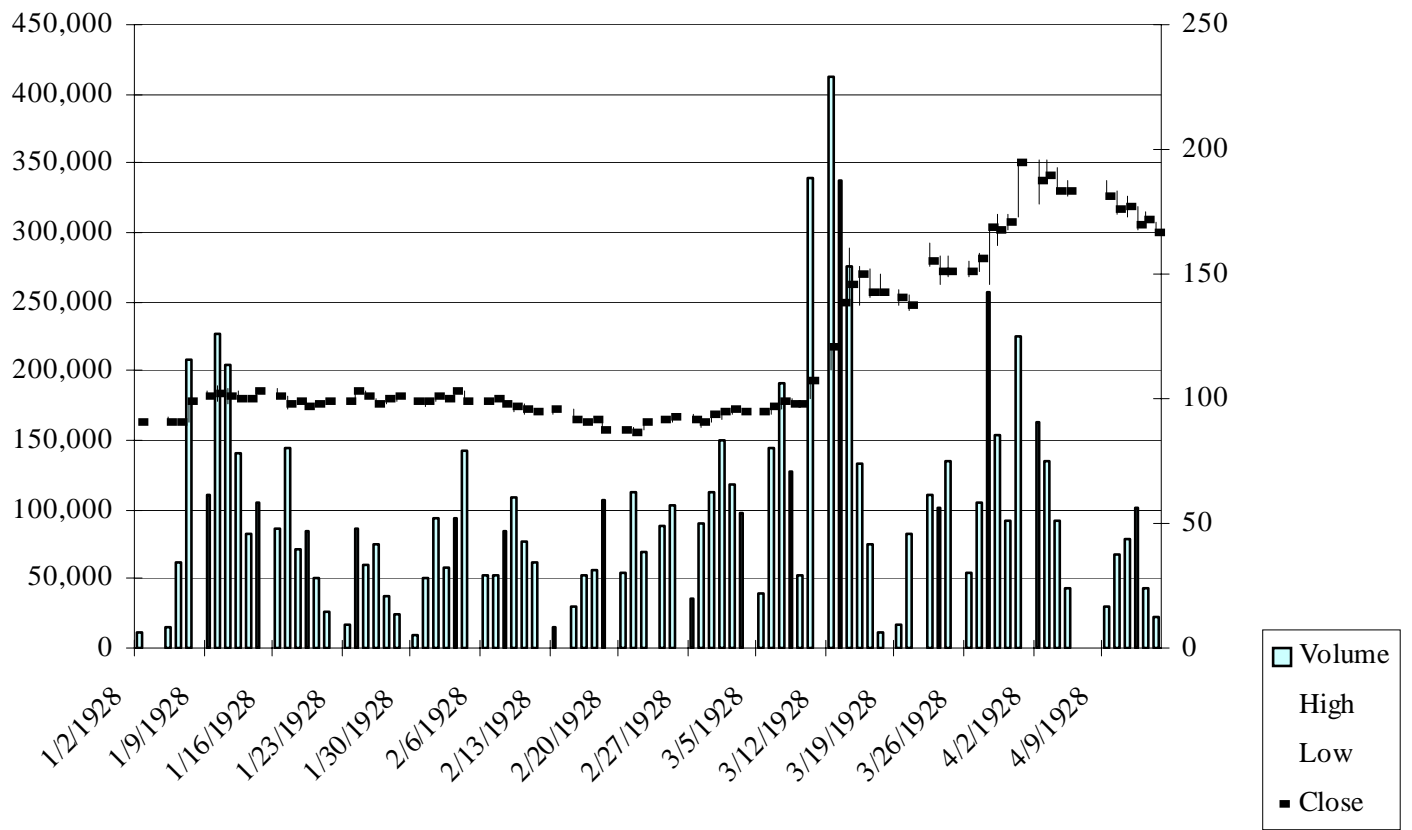

Figure 14A.

NYMEX Silver Futures 5000 Oz Contracts, Corner Date: 03/28/1980
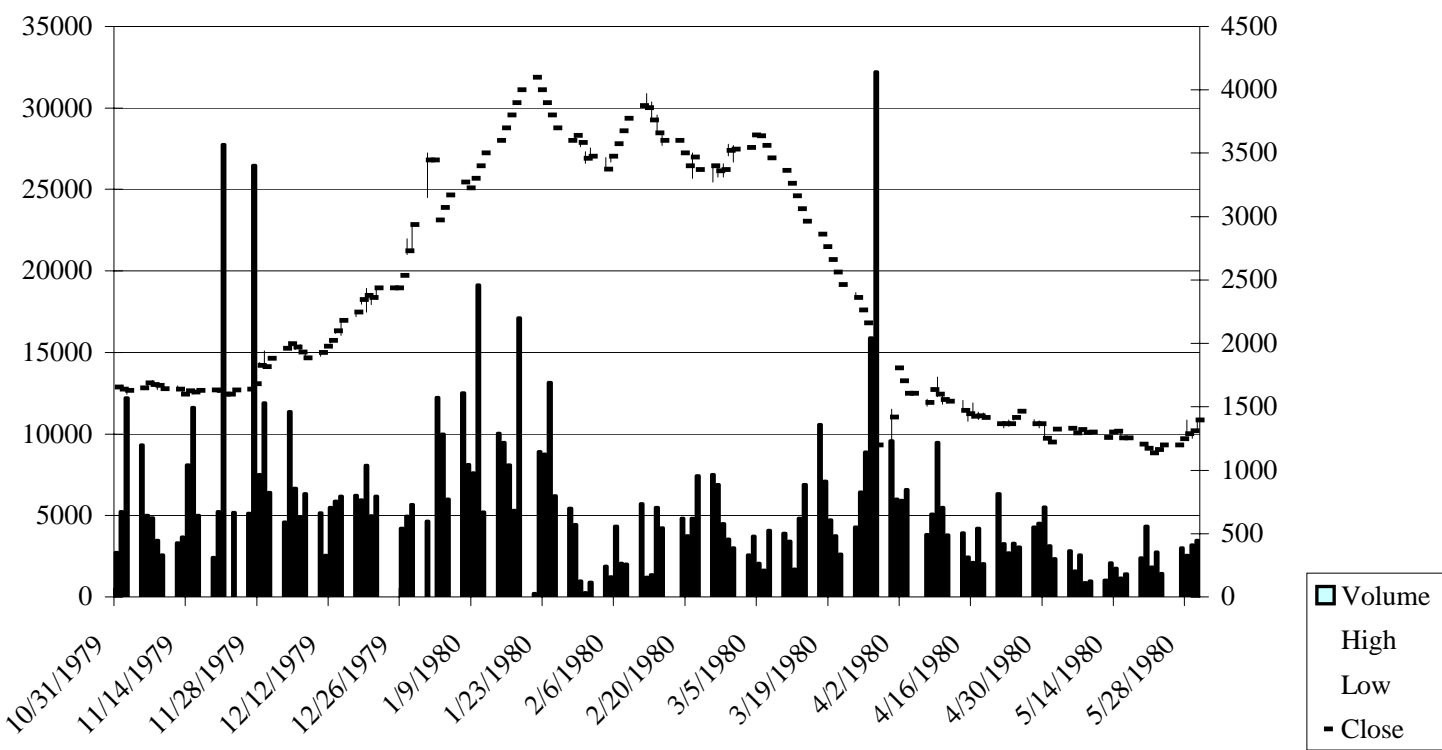